\title{
Targeting the Formyl Peptide Receptor type 1 to prevent the adhesion of ovarian cancer cells onto mesothelium and subsequent invasion
}

Michele Minopoli ${ }^{1}$, Giovanni Botti ${ }^{2}$, Vincenzo Gigantino ${ }^{3}$, Concetta Ragone ${ }^{1}$, Sabrina Sarno ${ }^{1,3}$, Maria Letizia Motti ${ }^{4}$, Giosuè Scognamiglio ${ }^{3}$, Stefano Greggi ${ }^{5}$, Cono Scaffa ${ }^{5}$, Maria Serena Roca ${ }^{6}$, Maria Patrizia Stoppelli ${ }^{7}$, Gennaro Ciliberto ${ }^{8}$, Nunzia Simona Losito ${ }^{3+}$ and Maria Vincenza Carriero ${ }^{1 * \dagger}$

\begin{abstract}
Background: The biological behavior of epithelial ovarian cancer (EOC) is unique since EOC cells metastasize early to the peritoneum. Thereby, new anti-target agents designed to block trans-coelomic dissemination of EOC cells may be useful as anti-metastatic drugs. The Urokinase Plasminogen Activator Receptor (UPAR) is overexpressed in EOC tissues, and its truncated forms released in sera and/or ascitic fluid are associated with poor prognosis and unfavorable clinical outcome. We documented that uPAR triggers intra-abdominal dissemination of EOC cells through the interaction of its 84-95 sequence with the Formyl Peptide Receptor type 1 (FPR1), even as short linear peptide Ser-Arg-Ser-Arg-Tyr (SRSRY). While the pro-metastatic role of uPAR is well documented, little information regarding the expression and role of FPR1 in EOC is currently available.
\end{abstract}

Methods: Expression levels of UPAR and FPR1 in EOC cells and tissues were assessed by immunofluorescence, Western blot, or immunohystochemistry. Cell adhesion to extra-cellular matrix proteins and mesothelium as well as mesothelium invasion kinetics by EOC cells were monitored using the XCELLigence technology or assessed by measuring cell-associated fluorescence. Cell internalization of FPR1 was identified on multiple z-series by confocal microscopy. Data from in vitro assays were analysed by one-way ANOVA and post-hoc Dunnett t-test for multiple comparisons. Tissue microarray data were analyzed with the Pearson's Chi-square $\left(X^{2}\right)$ test.

Results: Co-expression of UPAR and FPR1 by SKOV-3 and primary EOC cells confers a marked adhesion to vitronectin. The extent of cell adhesion decreases to basal level by pre-exposure to anti-uPAR84-95 Abs, or to the RI-3 peptide, blocking the uPAR84-95/FPR1 interaction. Furthermore, EOC cells exposed to RI-3 or desensitized with an excess of SRSRY, fail to adhere also to mesothelial cell monolayers, losing the ability to cross them. Finally, primary and metastatic EOC tissues express a high level of FPR1.

Conclusions: Our findings identify for the first time FPR1 as a potential biomarker of aggressive EOC and suggests that inhibitors of the uPAR84-95/FPR1 crosstalk may be useful for the treatment of metastatic EOC.

Keywords: Formyl peptide receptor, Urokinase receptor, Peptide, Ovarian cancer, Adhesion, Mesothelium

\footnotetext{
* Correspondence: m.carriero@istitutotumori.na.it

${ }^{\dagger}$ Nunzia Simona Losito and Maria Vincenza Carriero share senior authorship and should be considered co-last authors.

'Neoplastic Progression Unit, Istituto Nazionale Tumori IRCCS 'Fondazione G.

Pascale', Via M.Semmola, 80131 Naples, Italy

Full list of author information is available at the end of the article
}

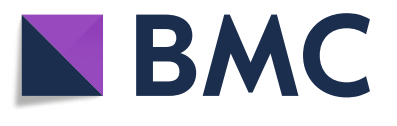

(c) The Author(s). 2019 Open Access This article is distributed under the terms of the Creative Commons Attribution 4.0 International License (http://creativecommons.org/licenses/by/4.0/), which permits unrestricted use, distribution, and reproduction in any medium, provided you give appropriate credit to the original author(s) and the source, provide a link to the Creative Commons license, and indicate if changes were made. The Creative Commons Public Domain Dedication waiver (http://creativecommons.org/publicdomain/zero/1.0/) applies to the data made available in this article, unless otherwise stated. 


\section{Background}

Epithelial ovarian cancer (EOC) is the 8th most common cause of death from cancer in women worldwide and its incidence rate is predicted to increase by $55 \%$ by 2035 [1-3]. Nowadays, the treatment for EOC is aggressive primary surgery followed by platinum-based chemotherapy. Nevertheless, the risk of relapse is high, even in patients who achieve a complete response, and most of them develop platinum-resistant progressive disease, which restricts available therapeutic options. Despite impressive advances in surgical approaches and drugs, the 5year survival for patients with advanced disease remains only about 30\% [4]. Furthermore, although many efforts have been made to develop new prognostic markers, few molecular prognostic signatures have been developed, fewer have been validated, and clinically available today [5-9]. The highly lethal malignancy for EOC is mainly due to its propensity to form widespread peritoneal implants throughout the abdominal cavity [10].

Ovarian cancer cells detach from the primary tumor and float in the ascitic fluid as single cells or multicellular, chemo-resistant spheroids [11]. Then, floating cancer cells must resist anoikis triggered by lack of attachment to the mesothelium to evade clearance through the peritoneal lymphatics. Thus, metastatic progression is fueled by the mesothelium-tumor cells interactions, which, if successfully blocked, may promote the death and clearance of cancer cells [12]. Metastasizing EOC cells exhibit a two-step mode: first adhere to exposed mesothelial extracellular matrix (ECM) proteins, and then penetrate ECM under mesothelial cells [13]. The Urokinase Plasminogen Activator (uPA) and its specific Receptor (UPAR) are very important at multiple stages during development of intraperitoneal metastases of ovarian cancer cells [14-17]. uPAR is a glycosyl-phosphatidylinositol (GPI)-anchored receptor arranged in three domains (DI, DII, and DIII) linked by short sequence regions [18]. When expressed on cell surface, uPAR promotes cell-associated proteolysis by binding to uPA, which locally converts plasminogen into active plasmin, thus favoring tissue invasion and metastasis [14, 19]. Plasmin generated by uPA or uPA itself can cleave intact UPAR (DI-DIII), releasing DI, while the remaining GPIanchored DII-DIII can remain on cell surface or be secreted in the extracellular milieu following cleavage of the anchor [20]. Indeed, full-length UPAR or fragments deriving from its cleavage on the cell surface may be released in soluble form in plasma and/or urine [21]. In EOC, overexpression of $\mathrm{UPAR}$ and the release of its truncated forms in sera and in the ascitic fluid, are associated with poor prognosis and unfavorable clinical outcome [17]. The domain boundary between DI-DII (uPAR84-95 sequence) is mainly projected on the external surface of UPAR, includes a protease-sensitive signaling region, and possesses a structural flexibility in both membrane-associated and soluble forms of uPAR $[22,23]$. We and others have documented that UPAR8495 sequence as well as the synthetic shorter pentapeptide uPAR88-92 (Ser-Arg-Ser-Arg-Tyr, SRSRY) act as potent regulators of cell migration and ECM attachment, independently of the uPA catalytic activity [14, 24-26]. Previous work from this laboratory showed that uPAR promotes ovarian cancer cell dissemination through its 84-95 sequence. Using hamster ovarian CHO-K1 cells lacking UPAR and stably transfected with cDNAs coding for UPAR containing or lacking the 84-95 sequence, we found that $\mathrm{uPAR}_{84-95}$ is indispensable for growth and intra-abdominal dissemination of ovarian cells orthotopically implanted in nude mice [27].

Mechanistically, uPAR84-95 and SRSRY exert these activities through their interaction with the Formyl Peptide Receptor type 1 (FPR1) which internalizes and activates the vitronectin receptor with an inside-out type of mechanism, involving $\mathrm{PKC}$, AKT and MAPK signaling cascades [26, 28].

Human FPR1, originally identified in neutrophils, monocytes and macrophages, has been shown in recent years, to be expressed also in many non-myelocytic cells. Aberrant expression of FPR1 was detected in tumors of different origin and reported as a negative prognostic factor [29-31]. While the role of UPAR in favoring intraabdominal dissemination of ovarian cancer cells is largely documented [17, 27], no data regarding expression and possible role of FPR1 on the surface of ovarian cancer cells are currently available. In the past years, we generated synthetic peptides containing the substitution of Ser90 with a glutamic acid or a $\alpha$-amino-isobutyric acid residue in the $\mathrm{Ser}^{88}$-Arg-Ser-Arg-Tyr ${ }^{92}$ sequence inhibiting the uPAR/FPR1 interaction, directional cell migration, invasion and angiogenesis [32-35]. Later, to improve their chemical stability and half-life, we developed a new library of retro-inverso peptides [36]. The lead compound Ac-(D)-Tyr-(D)-Arg-Aib-(D)-Arg- $\mathrm{NH}_{2}$ (RI-3) is stable in human serum, adopts the turn structure typical of uPAR/FPR1 antagonists, and competes with fMLF and SRSRY for binding to FPR1, preventing SRSRY-induced FPR1 internalization as well as p38 MAPK and PI3K/AKT signaling cascades [36], which are documented to mediate FPR1 signal transduction pathways [30]. Interestingly, RI-3 inhibits migration and invasion of sarcoma and melanoma cells in a dose dependent manner, an overall $50 \%$ reduction of cell migration and invasion being reached in the picomolar and nanomolar range, respectively [36, 37]. Recently, to understand the structural basis of the RI-3 inhibitory effects, the FPR1/fMLF, FPR1/SRSRY and FPR1/RI-3 complexes were modeled and analyzed, focusing on the binding pocket of FPR1 and the interaction between the 
amino acids that signal to the FPR1 C-terminal loop. We found that RI-3 shares the same binding site of fMLF and SRSRY on FPR1. However, while fMLF and SRSRY display the same agonist activation signature, RI-3 does not interact with the activation region of FPR1, keeping receptor anchored on cell membrane and hence unable to internalize and activate signaling, [38]. In this study, we analyzed the expression of FPR1 in tissues from patients affected by EOC. Then, by using primary EOC cells, we analyzed the role of uPAR/FPR1 crosstalk enabling cancer cells to adhere onto matrices and mesothelial cell monolayers. We also show that RI-3 successfully prevents the capability of ovarian cancer cells to adhere onto vitronectin and invade mesothelium.

\section{Methods}

\section{EOC cell line, EOC primary cultures and transfection}

Human ovarian carcinoma SKOV-3 and A2780 cell lines, obtained from the Cell Factory of the National Cancer Institute of Genova, were cultured in DMEM or RPMI, respectively, supplemented with $10 \%$ heat-inactivated fetal bovine serum (FBS), penicillin $(100 \mu \mathrm{g} / \mathrm{mL})$, streptomycin $(100 \mathrm{U} / \mathrm{mL})$ and maintained at $37^{\circ} \mathrm{C}$ in a humidified atmosphere of $5 \% \mathrm{CO}_{2}$. To obtain primary cultures, a representative sample from the EOC excision $(\sim 1 \mathrm{~cm} \times 1 \mathrm{~cm})$ of consenting patients (Table 1 ) was immediately minced by scalpel under sterile conditions, and incubated with 1.0 $\mathrm{mg} / \mathrm{mL}$ collagenase XI (Sigma) for $3 \mathrm{~h}$ at $37{ }^{\circ} \mathrm{C}$ under gentle agitation, as previously described [39]. Cells, recovered by centrifugation at $1500 \mathrm{rpm}$, were cultured in 6-well multi-dish plates in DMEM with the addition of 10\% FBS, $100 \mathrm{IU} / \mathrm{mL}$ penicillin and $50 \mu \mathrm{g} / \mathrm{mL}$ streptomycin. Isolated cell clusters were further amplified in growth medium until an adherent, homogeneous cell population was obtained. The epithelial phenotype was identified by the positive staining for the CD326 pan-epithelial differentiation antigen (Miltenyi Biotec).

SKOV-3 and primary EOC cells were stably transfected with cDNA coding for the Green Fluorescent Protein (GFP) using pEGFP-N1 vector (Clontech) and polyfectamine transfection reagent (Quiagen) as described [36]. Transfected cells were selected by Geneticin at $0.8 \mathrm{mg} / \mathrm{mL}$ for 15 days, pooled and cultured in the presence of $0.5 \mathrm{mg} / \mathrm{mL}$ Geneticin. G418-resistant cells expressing the highest levels of GFP were isolated and amplified.

\section{Flow cytometry}

Cells $\left(0.5 \times 10^{6}\right.$ cells/sample) were detached using 200 $\mathrm{mg} / \mathrm{L}$ EDTA, $500 \mathrm{mg} / \mathrm{L}$ trypsin (Cambrex) and incubated with $100 \mu$ phosphate buffered saline (PBS) containing diluents (CTRL), $10 \mu \mathrm{l}$ uPAR (CD87)-APC-conjugated antibody (Miltenyi Biotec), or $30 \mu \mathrm{l}$ FPR1 PE-conjugated Antibody (R\&D Sistems) for $10 \mathrm{~min}$ at $4{ }^{\circ} \mathrm{C}$ and $30 \mathrm{~min}$ at $23^{\circ} \mathrm{C}$, respectively. After extensive washing with PBS, cells were re-suspended in $0.4 \mathrm{ml}$ PBS and analyzed by flow cytometry using the BD FACSCanto II (BD Biosciences) and the FlowJo software. Control staining was performed using FITC-conjugated isotype-mached mouse IgG.

\section{Primary culture of mesothelial cells}

Human peritoneal mesothelial cells (HPMCs) were isolated and characterized as previously described [27]. Briefly, specimens of human omentum were obtained from consenting patients undergoing elective abdominal surgery $\left(\sim 2 \mathrm{~cm}^{2}\right)$. Blunt dissection removed excess fat and provided predominantly transparent samples of the tissue. The omentum was washed several times with sterile PBS to remove any contaminating red blood cells and specimens were subjected to disaggregation with 5 $\mathrm{mL}$ of $0.125 \%$ (wt/vol) trypsin, $0.01 \%$ (wt/vol) EDTA (Sigma) for $20 \mathrm{~min}$ at $37^{\circ} \mathrm{C}$ with continuous rotation. Then, cell suspension was centrifuged at $800 \times$ g for 5 min, the cell pellet was washed once in F12 culture medium containing $10 \%$ FBS, suspended in the same medium to a volume of $5 \mathrm{~mL}$ and seeded in $25 \mathrm{~cm}^{2}$ tissue culture flasks. Half the medium was changed $24 \mathrm{~h}$ later and fully replaced once every 3 days. The mesothelial phenotype was identified by the uniform cobblestone appearance at confluence, by the lack of staining for factor VIII-related antigen, and by the positive staining for cytokeratin 8 and 18 (Clone EP17/EP30) and vimentin, all purchased by Dako.

\section{Peptides}

The peptides SRSRY, ARARY and Ac-(D)-Tyr-(D)-ArgAib-(D)-Arg-NH2 (RI-3) were custom-synthesized by JPT Peptide Technologies, Germany. Peptides were

Table 1 Clinicopathologic findings, UPAR and FPR1 expression in EOC tissues

\begin{tabular}{llllllll}
\hline Patients & Age & Site & Size $(\mathrm{cm})$ & Histology & FIGO & uPAR score & FPR1 score \\
\hline 1 & 64 & right ovary & $10 \times 10 \times 8$ & HGSC & III & 2 & 1 \\
2 & 44 & left ovary & $11 \times 9 \times 6.5$ & HGSC & IV & 1 & 2 \\
3 & 62 & left ovary & $2.5 \times 1 \times 1$ & HGSC & III & 1 & 2 \\
4 & 62 & left ovary & $4 \times 3 \times 2$ & HGSC & III & 2 & 2 \\
5 & 49 & left ovary & $4 \times 2 \times 0.5$ & HGSC & III & 2 & 2 \\
\hline
\end{tabular}


synthesized on solid-phase with Fmoc/t-Bu chemistry and purified by reversed-phase HPLC using water/acetonitrile gradients, and characterized by UPLC-MS. NFormyl-L-methionyl-L-leucyl-L-phenylalanine (fMLF) and the fluorescein conjugate hexapeptide Formyl-NleLeu-Phe-Nle-Tyr-Lys (FITC-fMLF) peptides were purchased by Invitrogen and Molecular Probes, respectively. The fluorescein-conjugate Ac-(D)-Tyr-(D)-Arg-Aib-(D)Arg-Ahx-Lys ( ${ }^{\varepsilon}$-FITC)- $\mathrm{NH}_{2}$ (FITC-RI-3) peptide was custom-synthesized by MicroGem, Italy.

\section{Western blot}

Cells detached using $200 \mathrm{mg} / \mathrm{L}$ EDTA, $500 \mathrm{mg} / \mathrm{L}$ trypsin (Cambrex), were lysed in RIPA buffer $(10 \mathrm{mM}$ Tris $\mathrm{pH}$ 7.5, $140 \mathrm{mM} \mathrm{NaCl}, 0.1 \%$ SDS, $1 \%$ Triton X-100, $0.5 \%$ NP40) containing protease inhibitor mixture. Protein content of cell lysates was measured by a colorimetric assay (BioRad). 30 and $60 \mu \mathrm{g}$ proteins were separated on $10 \%$ SDS-PAGE under unreducing (to detect uPAR) or reducing conditions (to detect FPR1) and transferred onto a polyvinylidene fluoride membrane. Membranes were blocked with 5\% non-fat dry milk and probed with $1 \mu \mathrm{g} / \mathrm{mL} \mathrm{R} 4$ anti-uPAR mAb, recognizing the DII-DIII uPAR domains, $1 \mu \mathrm{g} / \mathrm{mL}$ anti-FPR1 polyclonal antibody (Ab) (\#128296 Ab, Abcam), or $0.2 \mu \mathrm{g} / \mathrm{mL}$ GAPDH Ab (Santa Cruz Biotechnology). Washed filters were incubated with horseradish peroxidase-conjugated antimouse or anti-rabbit antibody and detected by ECL (Amersham- GE Healthcare). Densitometry was performed using the NIH Image 1.62 software (Bethesda, MD.

\section{Adhesion of EOC cells onto extracellular matrix proteins}

Adhesion assays were performed using 24 multi-well plates coated with $1 \% \mathrm{BSA}, 5 \mu \mathrm{g} \mathrm{mL}$ vitronectin $(\mathrm{Vn})$, $5 \mu \mathrm{g} \mathrm{mL}$ fibronectin (Fn), $5 \mu \mathrm{g} \mathrm{mL}$ laminin $(\mathrm{Lm})$ or $15 \mu \mathrm{g}$ $\mathrm{mL}$ collagen (Coll) diluted in serum-free medium. Subconfluent cells were harvested by a mild trypsinization, incubated with $10 \%$ FBS / DMEM for $1 \mathrm{~h}$ at $37^{\circ} \mathrm{C}, 5 \%$ $\mathrm{CO}_{2}$, acid treated with a buffer containing $50 \mathrm{mM}$ glycin- $\mathrm{HCl}, 0.1 \mathrm{M} \mathrm{NaCl}, \mathrm{pH} 3$ for $4 \mathrm{~min}$ at $22^{\circ} \mathrm{C}$, to remove receptor-bound ligands [40], and counted. Viable cells $\left(2 \times 10^{5}\right.$ cells per well) were plated in serum-free medium, in the absence or presence of $2 \mu \mathrm{g} / \mathrm{mL}$ R3 $\mathrm{mAb}$ recognizing the DI uPAR domain, $2 \mu \mathrm{g} / \mathrm{mL} 399$ antiuPAR (American Diagnostica), $2 \mu \mathrm{g} / \mathrm{mL}$ anti-uPAR84-95 (PRIMM), $2 \mu \mathrm{g} / \mathrm{mL}$ anti- $\alpha$-tubulin (Cell Signaling) Abs or $10 \mathrm{nM}$ RI-3, and allowed to adhere for $2 \mathrm{~h}$ at $37^{\circ} \mathrm{C}$, $5 \% \mathrm{CO}_{2}$. A subset of experiments was performed using cells desensitized with $100 \mathrm{nM}$ SRSRY, $100 \mathrm{nM}$ fMLF to block FPR1 activity as described [28], or $100 \mathrm{nM}$ control peptide ARARY for $30 \mathrm{~min}$ at $37^{\circ} \mathrm{C}$ in humidified air with $5 \% \mathrm{CO}_{2}$. At the end of the assay, adherent cells were removed with $0.05 \%$ trypsin, and counted. The number of adherent cells was expressed as a percentage of the basal cell adhesion (CTRL). The experiments were performed at least three times in triplicate.

\section{Adhesion kinetic of EOC cells monitored in real time}

This assay was performed using E-16-well plates and the xCELLigence Real Time Cell Analysis technology. Bottom wells were coated with serum-free medium, $5 \mu \mathrm{g}$ $\mathrm{mL}$ Vn, $5 \mu \mathrm{g} \mathrm{mL} \mathrm{Fn,} 5 \mu \mathrm{g} \mathrm{mL} \mathrm{Lm} \mathrm{or} 15 \mu \mathrm{g} \mathrm{mL} \mathrm{Coll} \mathrm{di-}$ luted in serum-free medium prior to seeding cells $(1 \times$ $10^{4}$ cells/well) suspended in in serum-free medium. Cells that adhere to the bottom of plates cause impedance changes which are proportional to the number of cells. The impedance value of each well was automatically monitored in real-time for at least $2 \mathrm{~h}$ and expressed as a cell index value. The experiments were performed three times in quadruplicate.

\section{EOC cell adhesion onto mesothelium}

HPMCs $\left(1 \times 10^{5}\right.$ cells/well $)$ suspended in growth medium, were seeded in 24-well plates and allowed to adhere for about $20 \mathrm{~h}$ until they form a confluent monolayer, prior to seeding GFP-tagged EOC cells suspended in growth medium plus diluents or $10 \mathrm{nM}$ RI-3. At the indicated times, plates were accurately washed with PBS and cell-associated fluorescence was assessed by a fluorescence plate reader a fluorescence plate reader (Victor 3, Perkin Elmer), using $485 \mathrm{~nm}$ excitation and $535 \mathrm{~nm}$ emission filters. The experiments were performed three times in triplicate.

\section{HPMC invasion by EOC cells monitored in real time}

HPMCs $\left(5 \times 10^{3}\right.$ cells/well $)$ suspended in growth medium, were seeded in E-16-well plates and allow to adhere for $18-20 \mathrm{~h}$ until they form a confluent monolayer [27], prior to seeding EOC cells $\left(2 \times 10^{4}\right.$ cells/well $)$ in growth medium plus/minus $10 \mathrm{nM}$ RI-3. When HPMCs are challenged with invading cells, there is a drop in electrical resistance within $2-4 \mathrm{~h}$ which is monitored in real-time as the Cell Index changes due to the rupture of mesothelium. The experiments were performed three times in quadruplicate.

\section{Fluorescence microscopy}

Cells $\left(2 \times 10^{4} /\right.$ sample $)$ were seeded on glass coverslips and cultured for $24 \mathrm{~h}$ in growth medium. Then, slides were washed with PBS, fixed with $2.5 \%$ formaldehyde in PBS for $10 \mathrm{~min}$ at $4{ }^{\circ} \mathrm{C}$ and incubated for $1 \mathrm{~h}$ at $4{ }^{\circ} \mathrm{C}$ with $2 \mu \mathrm{g} / \mathrm{mL}$ R4 anti-uPAR mAb or 1:100 rabbit anti-FPR1 $\mathrm{Ab}$ (\#113531Ab, Abcam). Then, 1:700 goat Alexa Fluor 488 anti-rabbit IgG, or rabbit Alexa Fluor 488conjugated $\mathrm{F}(\mathrm{ab}$ ') 2 fragment of anti-mouse IgG (Molecular Probes) were applied to slides at $23^{\circ} \mathrm{C}$ for $40 \mathrm{~min}$. Nuclear staining was performed with 4-6-diamidino-2- 
phenylindole dye (DAPI). To analyze agonist-dependent FPR1 internalization, cells grown on glass slides were exposed to $10 \mathrm{nM}$ FITC-fMLF or $10 \mathrm{nM}$ FITC-RI-3 diluted in serum-free DMEM for $30 \mathrm{~min}$ at $37^{\circ} \mathrm{C}$ as described [32, 38]. After extensive washing with PBS, coverslips were mounted using $20 \%(\mathrm{w} / \mathrm{v})$ mowiol, visualized with the 510 META-LSM confocal microscope (Carl Zeiss).

\section{Ligand binding assay}

EOC cells were pre-incubated with diluents or the indicated unlabeled peptides for $60 \mathrm{~min}$ at $4{ }^{\circ} \mathrm{C}$ (to avoid internalization), extensively rinsed with phosphate buffer saline (PBS), exposed to $10 \mathrm{nM}$ FITC-RI-3 diluted in PBS, for additional $60 \mathrm{~min}$ at $4{ }^{\circ} \mathrm{C}$ and again rinsed with PBS. Quantification of cell associated fluorescence was assessed by reading cells with the fluorescence plate reader Victor 3. The experiments were performed three times in duplicate.

\section{EOC patients}

Forty-two patients admitted to the National Cancer Institute of Naples were recruited in the study. All patients provided written informed consent for the use of samples according to the institutional regulations and the study was approved by the ethics committee of the National Cancer Institute of Naples. All EOC cases were reviewed according to 2014 WHO classification criteria [41], using standard tissue sections and include: $n=3$ low-grade serous carcinoma (LGSC), $n=33$ high-grade serous carcinoma (HGSC), $n=5$ ovarian clear cell carcinoma (OCCC), and $n=1$ mucinous ovarian carcinoma $(\mathrm{mEOC})$ tissues. Medical records have been reviewed for clinical information, including histologic parameters assessed on standard H\&E-stained slides.

\section{TMA building}

A tissue microarray (TMA) was built using 37 EOC tissue samples, including 17 primary and matched metastatic tissues. Tissue cylinders with a diameter of $1 \mathrm{~mm}$ were punched from morphologically representative tissue areas of each 'donor' tissue block and brought into one recipient paraffin block $(3 \times 2.5 . \mathrm{cm})$ using a semiautomated tissue array (Galileo TMA).

\section{Immunohistochemistry}

Immunohistochemistry (IHC) was carried out on slides from formalin-fixed, paraffin-embedded tissues, in order to evaluate the expression of UPAR (on 5 HGSC cases) and FPR1. Paraffin slides were deparaffinized in xylene and rehydrated through graded alcohols. Antigen retrieval was performed with slides heated in $0.01 \mathrm{M}$ citrate buffer (pH 6.0.) in a bath for $20 \mathrm{~min}$ at $97^{\circ} \mathrm{C}$. After antigen retrieval, the slides were allowed to cool, rinsed with Tris buffered saline (TBS) and the endogenous peroxidase was inactivated with $3 \%$ hydrogen peroxide as described [42, 43]. After protein block (5\% BSA in PBS), the slides were incubated overnight at $4{ }^{\circ} \mathrm{C}$ with $1 \mu \mathrm{g} / \mathrm{mL}$ rabbit anti-human FPR1 polyclonal Ab (cod. NLS2086, Novus Biologicals) or the R4 anti-uPAR mAb, recognizing the DIIDIII uPAR domains (Dako). Then, sections were incubated with mouse biotin anti-rabbit or goat anti-mouse secondary IgG Abs for $30 \mathrm{~min}$. Immunoreactivity was visualized by means of avidin-biotinperoxidase complex kit reagents (Novocastra, Newcastle, UK) and the chromogenic substrate. Finally, sections were counterstained with hematoxylin and mounted. Appropriate inner cells were considered as controls. For each antibody, cytoplasmic and membrane staining were recorded. The UPAR and FPR1 staining intensity of epithelial tumor cells were graded as faint (score 0), moderate (score 1), or intense (score 2). TMA tissues were scored semi-quantitatively by evaluating the proportion of positive tumor cells over the total number of tumor cells (percentage of positive tumor cells/tissue microarray punch). Negative/low and positive high expressing tissues were recorded when neoplastic cells expressing FPR1 were between 0 and $10 \%$, and $\geq 80 \%$, respectively. All sections were evaluated in a blinded fashion by 2 investigators.

\section{Statistical analysis}

The results are expressed as the means \pm standard deviations of the number of the indicated determinations. Data derived from in vitro experiments were analyzed by one-way ANOVA and post hoc Dunnett t-test for multiple comparisons. $P<0.05$ was accepted as significant. Pearson's Chi-square $\left(x^{2}\right)$ test was used to analyze the correlations between FPR1 expression and clinicopathologic parameters. Data analysis and summarization were conducted using the SPSS 20.0 software (SPSS Inc., Chicago, Illinois USA).

\section{Results}

Requirement of uPAR84-95 and FPR1 for the adhesion of SKOV-3 cells onto vitronectin

Metastasizing EOC cells attach to the peritoneum through the interaction with exposed mesothelial ECM proteins [13]. We investigated the specific contribution of the uPAR84-95 chemotactic sequence in regulating the adhesion of SKOV-3 human ovarian carcinoma cells to the ECM proteins. Adhesion assays were performed by plating cells onto vitronectin ( $\mathrm{Vn}$ )-, collagen (Coll)-, fibronectin (FN)-, laminin (LM)- or BSA- coated wells, the last as control (CTRL). SKOV-3 cells, expressing a considerable amount of uPAR and FPR1 [27], were able to adhere to all tested ECM proteins, although at a different extent (Fig. 1a). However, as already documented [35], only cell adhesion onto $\mathrm{Vn}$ is uPAR 84-95- 

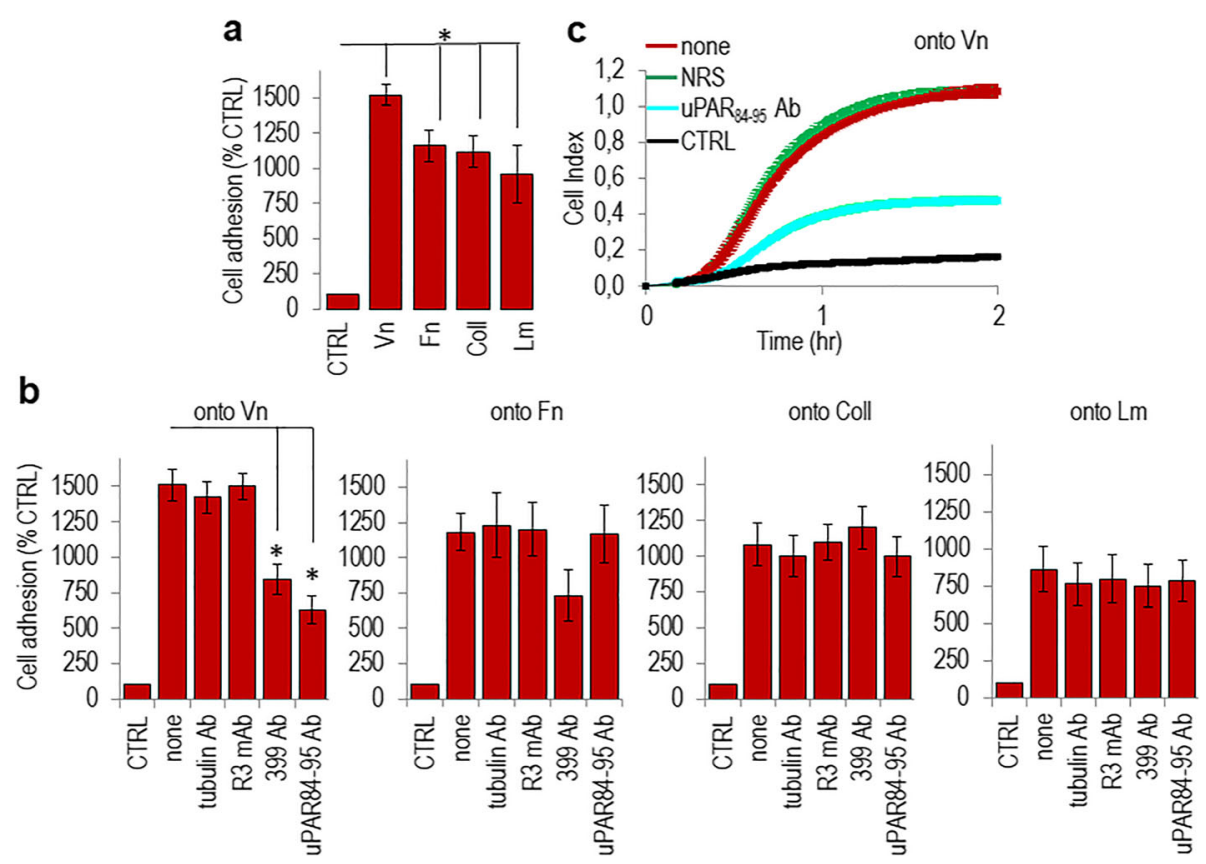

Fig. 1 Requirement of the UPAR84-95 sequence for SKOV-3 cell adhesion onto vitronectin. a. Viable SKOV-3 cells $\left(2 \times 10^{5}\right.$ cells/well) were seeded in triplicate in 24-well plates coated with 1\% BSA (CTRL), $5 \mu \mathrm{g} \mathrm{mL}$ vitronectin (Vn), $5 \mu \mathrm{g} \mathrm{mL}$ fibronectin (Fn), $5 \mu \mathrm{g} \mathrm{mL}$ laminin (Lm) or $15 \mu \mathrm{g} \mathrm{mL}$ collagen (Coll) and allowed to adhere for $2 \mathrm{~h}$. The number of adherent cells was expressed as a percentage of CTRL. Data are the means \pm SD of three independent experiments with ${ }^{*} P<0.001$. b. Cell adhesion of SKOV-3 cells in 24-well plates coated with $1 \%$ BSA (CTRL) or indicated matrix proteins in the absence (none) or presence of $2 \mu \mathrm{g} / \mathrm{ml} \mathrm{R3}$ anti-uPAR mAb, $2 \mu \mathrm{g} / \mathrm{ml} 399$ anti-uPAR Ab, $2 \mu \mathrm{g} / \mathrm{ml}$ anti-uPAR84-95 Ab, or $2 \mu \mathrm{g} / \mathrm{ml}$ anti-a-tubulin Ab for $2 \mathrm{~h}$. The number of adherent cells was expressed as a percentage of CTRL. Data are the means \pm SD of three independent experiments with ${ }^{*} P<0.001$. c. Adhesion of SKOV-3 cells onto Vn monitored by the $x$ CELLigence system. Cells $\left(1 \times 10^{4}\right.$ cells/well) suspended in serum-free medium (CTRL) with or without $2 \mu \mathrm{g} / \mathrm{ml}$ anti-uPAR84-95 or $2 \mu \mathrm{g} / \mathrm{ml}$ normal rabbit serum (NRS) were seeded on Vn-coated E-plates. The impedance value of each well was automatically monitored in real-time for $2 \mathrm{~h}$ and expressed as a cell index value. Data represent mean \pm SD from a quadruplicate experiment representative of 3 replicates

dependent because it is reduced to the basal level by cell pre-exposure to \#399 anti-uPAR as well as by antiuPAR84-95 Abs. In contrast, the R3 anti-uPAR mAb, recognizing the D1 uPAR domain or control antitubulin Ab were ineffective (Fig. 1b). Similar results were obtained when SKOV-3 cell adhesion onto Vn was monitored in real time for $2 \mathrm{~h}$, showing that adherence to $\mathrm{Vn}$ is prevented by anti-uPAR84-95 Ab, but not by normal rabbit serum (Fig. 1c). The involvement of FPR1 was tested by desensitizing cells with $100 \mathrm{nM}$ fMLF (Fig. 2a) or $100 \mathrm{nM}$ SRSRY (Fig. 2b) for $30 \mathrm{~min}$ at $37^{\circ} \mathrm{C}$, leading to unavailability of FPR1 on cell surface $[37,38]$. Desensitized cells lose the ability to adhere onto Vn but not onto Coll, Fn or Lm (Fig. 2a-b). Real time assessment of cell adhesion onto Vn, allowed us to confirm that preexposure to an excess of fMLF or SRSRY abrogates cell capability to adhere onto Vn, whereas the ARARY control peptide is ineffective (Fig. 2c). To further analyse the role of uPAR/FPR1 complexes in favoring cell adhesion onto $\mathrm{Vn}, \mathrm{SKOV}-3$, cells were allowed to adhere onto $\mathrm{Vn}$ in the presence/absence of the retroinverso peptide RI-3 that binds FPR1 keeping it anchored to cell membrane and incapable to function [38]. We found that $10 \mathrm{nM}$
RI-3 neither affected basal cell adhesion, nor cell adhesion to Coll- Fn- and Lm-coated plates, but dramatically reduced the extent of cell adhesion onto Vn (Fig. 2d-e). Confirmatory experiments were performed using A2780 human ovarian carcinoma cells which neither express uPAR nor FPR1 on cell surface, as shown by Fax analysis (Additional file 1: Figure S1a). A2780 cells adhere at a different extent onto Coll, Fn or Lm, but they lack adhesion to $\mathrm{Vn}$, as expected on the basis of the missing uPAR84-95 and FPR1 receptors. As expected, in the absence of the target receptor, RI-3 peptide was ineffective (Additional file 1: Figure S1b).

\section{RI-3 prevents mesothelium invasion by SKOV-3 ovarian cancer cells}

Using hamster ovarian $\mathrm{CHO}-\mathrm{K} 1$ cells engineered to expose or lacking the 84-95 sequence, we have previously documented that the $\mathrm{uPAR}_{84-95}$ is required for cell capability to adhere to and cross mesothelial cell monolayers [27]. To ascertain if RI-3 peptide may affect SKOV-3 ovarian cell adhesion, mesothelial cells were purified from human omental specimens as previously described [27]. Pure mesothelial cells (HPMCs) were 


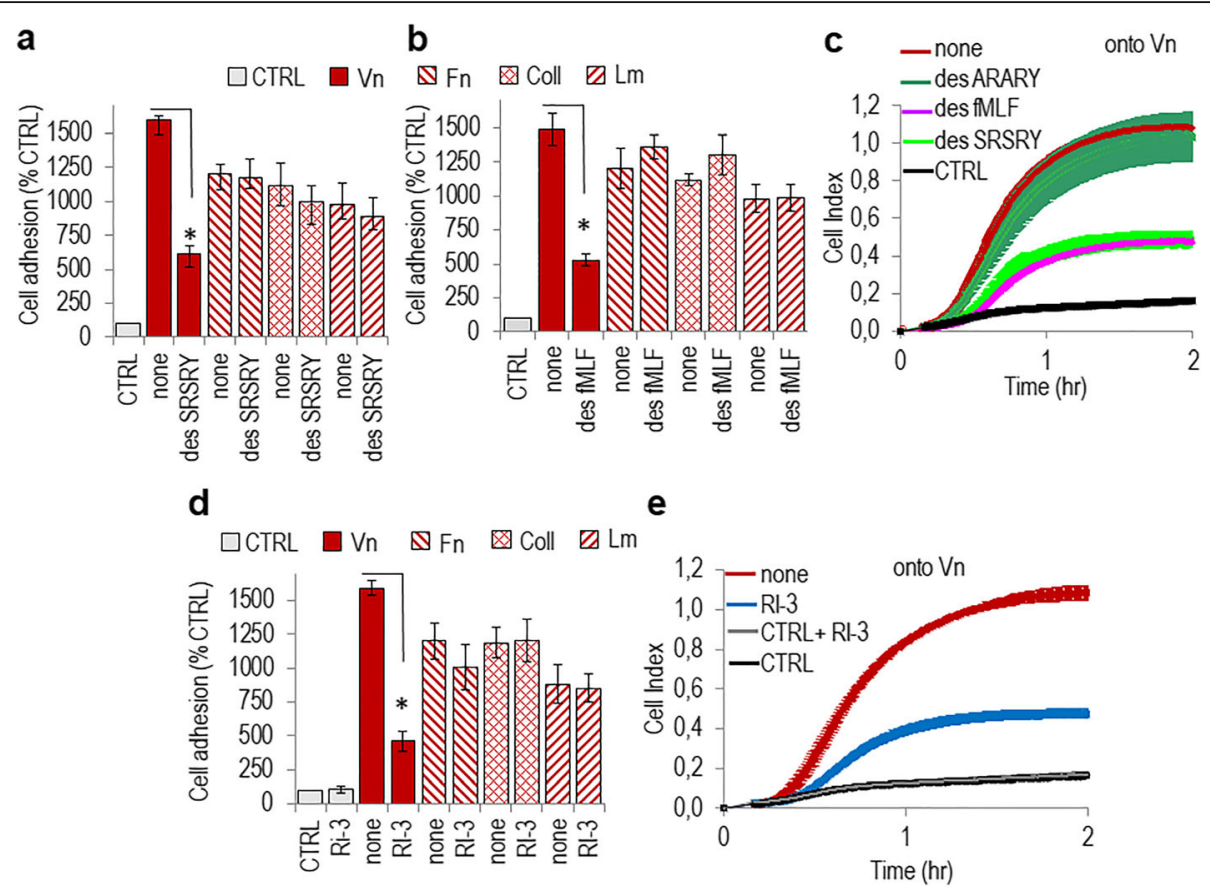

Fig. 2 FPR1 requirement for adhesion of SKOV-3 cells onto vitronectin. a-b. Cell adhesion of SKOV-3 cells pre-incubated with serum-free medium (none), $100 \mathrm{nM}$ SRSRY (a) or $100 \mathrm{nM}$ fMLF (b) for $37 \mathrm{~min}$ at $37^{\circ} \mathrm{C}$ in humidified air with $5 \% \mathrm{CO}_{2}$, onto the indicated matrix proteins. Cell adhesion was expressed as percentage of CTRL (cells adherent to plated coated with 1\% BSA). Data are the means \pm SD of three independent experiments with ${ }^{*} P<0.001$. c. Adhesion onto Vn of SKOV-3 cells desensitized with diluents (none), $100 \mathrm{nM}$ SRSRY, $100 \mathrm{nM}$ fMLF, or $100 \mathrm{nM}$ ARARY, monitored in real time for $2 \mathrm{~h}$ by the xCELLigence system. Data represent mean \pm SD from a quadruplicate experiment representative of 3 replicates. $\mathbf{d}$. Adhesion of SKOV-3 cells onto the indicated matrix proteins in the absence or presence of $10 \mathrm{nM} \mathrm{RI-3.} \mathrm{The} \mathrm{number} \mathrm{of} \mathrm{adherent} \mathrm{cells} \mathrm{was}$ expressed as a percentage of CTRL (cells adherent to plated coated with 1\% BSA). Data are the means \pm SD of three independent experiments with ${ }^{*} P<0.001$. e. Adhesion of SKOV-3 cells onto $\mathrm{Vn}$ in the absence or presence of $10 \mathrm{nM} \mathrm{RL}-3$, monitored in real time for $2 \mathrm{~h}$ by the $\times C E L L i g e n c e$ system. Data represent mean \pm SD from a quadruplicate experiment representative of 3 replicates

identified by their cobblestone appearance at semiconfluence (Fig. 3a), and because $87 \%$ of cells appeared positive for cytokeratin 8/18 (green) and vimentin (red) (Fig. 3b). Mesothelial cells were allowed to form a monolayer and Green Fluorescent Protein (GFP)-tagged SKOV-3 cells were seeded on top in the presence/absence of $10 \mathrm{nM}$ RI-3. At the indicated times, nonadherent cells were removed and the cell-associated fluorescence was measured using a fluorescence plate reader. GFP-SKOV-3 cells adhere early to mesothelium: already after 5-10 min, we found an appreciable cell adhesion to mesothelium, that increased with time. After $5,10,20$, and $40 \mathrm{~min}, 10 \mathrm{nM}$ RI-3 reduced cell associated fluorescence by $57,47,58$, and $54 \%$, respectively (Fig. $3 c$ ), indicating that the attachment of SKOV-3 cells to mesothelium is prevented by the RI-3 peptide. To investigate whether, RI-3 peptide also reduces mesothelium invasion by ovarian cancer cells, the ability of SKOV-3 cells to cross mesothelial cell monolayers was analyzed in the presence or the absence of RI-3, using the xCELLigence technology. As expected, an appreciable reduction of mesothelium integrity was achieved by SKOV-3 cells. In contrast, $10 \mathrm{nM}$ RI-3 abrogated the capability of
SKOV-3 cells to disrupt mesothelial cell monolayer (Fig. $3 \mathrm{~d}-\mathrm{e})$. In contrast, A2780 cells exhibited a poor ability to cross mesothelium and RI-3 added at $10 \mathrm{nM}$ concentration was ineffective (Additional file 1: Figure S1c). Taken together, these data indicate that the RI-3 peptide reduces SKOV-3 cell adhesion to vitronectin and mesothelial cell monolayers, both processes being sustained by the uPAR84-95/FPR1 crosstalk.

\section{Co-ordinated UPAR and FPR1 expression in human ovarian cancer tissues}

While the UPAR role in promoting intra-abdominal dissemination of ovarian cancer cells is largely documented [17], to the best of our knowledge, the expression of FPR1 in EOC tissues has never been reported. Thus, we analyzed the UPAR and FPR1 expression on formalinfixed paraffin-embedded sections from five serous adenocarcinoma tissues by IHC. Table 1 reports clinical data, pathological findings and FIGO staging of $n=5$ HGSC cases. The uPAR and FPR1 staining intensity of epithelial tumor cells was graded as faint (score 0), moderate (score 1), or intense (score 2) (Table 1) and representative patterns are shown in Fig. 4. Except for the 
a

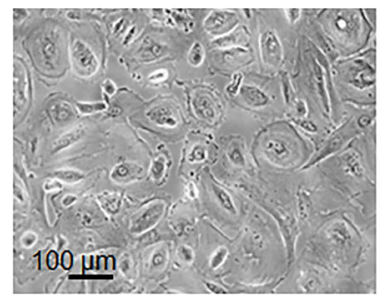

b

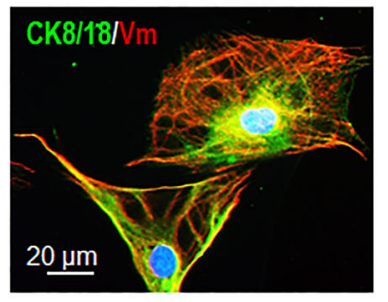

d

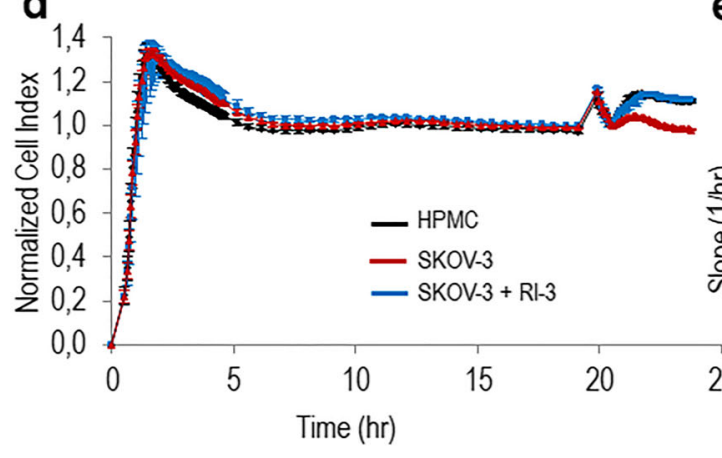

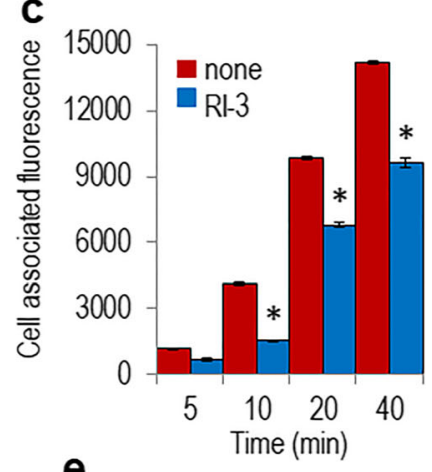

e

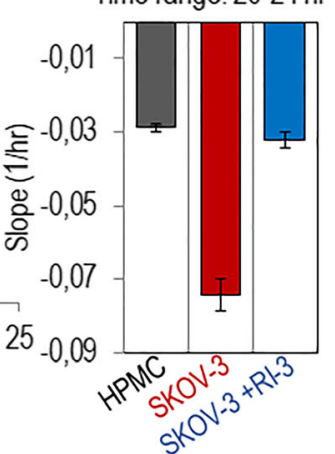

Fig. 3 Rl-3 prevents mesothelial cell adhesion and invasion by SKOV-3 cells. HPMCs were purified from human omental specimens and cultured as described in the Methods. a-b. Representative images of HPMCs visualized by phase contrast microscopy (a) or stained for cytokeratin 8/18 (green) and vimentin (red) (b). Nuclei were stained blue with DAPI. Original magnification: 400x (a), $1000 \times$ (b). c. HPMCs were seeded in 24-well plates and allowed to attach and form a monolayer for about $20 \mathrm{~h}$ prior to seeding GFP-SKOV-3 cells suspended in complete medium plus diluents (none), or $10 \mathrm{nM} \mathrm{Rl}-3$ at $37^{\circ} \mathrm{C}, 5 \% \mathrm{CO}_{2}$. At the indicated times, cell associated fluorescence was assessed by a fluorescence plate reader. Data represent means \pm SD of three independent experiments performed in triplicate with ${ }^{*} P<0.0001$ vs none. $\mathbf{d}$-e. Mesothelium invasion by SKOV-3 cells. HPMCs $\left(5 \times 10^{3}\right.$ cells/well) were seeded in E-16-well plates in growth medium and allow to adhere for $20 \mathrm{~h}$ until they form a confluent monolayer (plateau curves). Then, SKOV-3 cells $\left(2 \times 10^{4}\right.$ cells/well) suspended in growth medium plus/minus $10 \mathrm{nM}$ RI-3 were seeded on mesothelial cell monolayer. The invasion of mesothelium by SKOV-3 cells was monitored in real-time as changes in Cell Index due to breaking of the monolayer integrity (d). Slopes represent the change rate of Cell Indexes generated in a $20-24 \mathrm{~h}$ time frame (e). Data represent mean \pm SD from a quadruplicate experiment representative of 3 replicates

HGSC case \#3 showing only cell clusters reactive to R4 anti-uPAR mAb, all tumors exhibit a diffuse, heterogeneous pattern of staining, mainly localized on tumor plasma cell membranes (Fig. 4). A diffuse staining of the epithelial tumor cells using anti-FPR1 Ab was obtained in all sections, with a prominent staining of plasma cell membranes, often observed in positive tumor cells. No apparent detection of either UPAR and FPR1 was appreciated in intra-or peri-tumoral stroma with the exception of FPR1 expressing macrophages as already documented [44]. According to Ahmed and colleagues, we found no expression of UPAR in normal ovarian tissues [45], while FPR1staining of ciliated epithelium of healthy fallopian tubes adjacent to neoplastic areas was observed only in the HGSC case \#4 (not shown).

In order to obtain primary cultures of EOC cells, representative fragments of tissue samples were fragmented and cells recovered, as described in the Methods. By enzymatic digestion of a HGSC tissue sample (patient \#5), a primary cell culture expressing high levels of both UPAR and FPR1 on cell surface as shown by IHC, was obtained (Figs. 4 and 5a). Subsequent sub-cloning of isolated cell clusters (Fig. 5b) followed by five passages allowed us to obtain an adherent, homogeneous, CD326 positive cell population. These EOC cells express a considerable amount of both uPAR and FPR1 as shown by Western blot analysis of cell lysates and immunofluorescence experiments with Anti-uPAR mAb and anti-FPR1 $\mathrm{Ab}$ (Fig. 5c, d, e) and Additional file 1: Figure S2 for full blots). Competition binding assays with FITC-RI-3 that we have previously reported binding FPR1 and inhibiting cell migration like the non-fluorescent peptide [38], revealed a specific, saturable RI-3 uptake on EOC cell surface, which was prevented by either SRSRY and fMLF peptides (Fig. 5f). As expected, when binding experiments were carried out at $37^{\circ} \mathrm{C}$, FITC-fMLF caused FPR1 internalization as revealed by punctuate green fluorescent intra-cytoplasmic spots which were only 

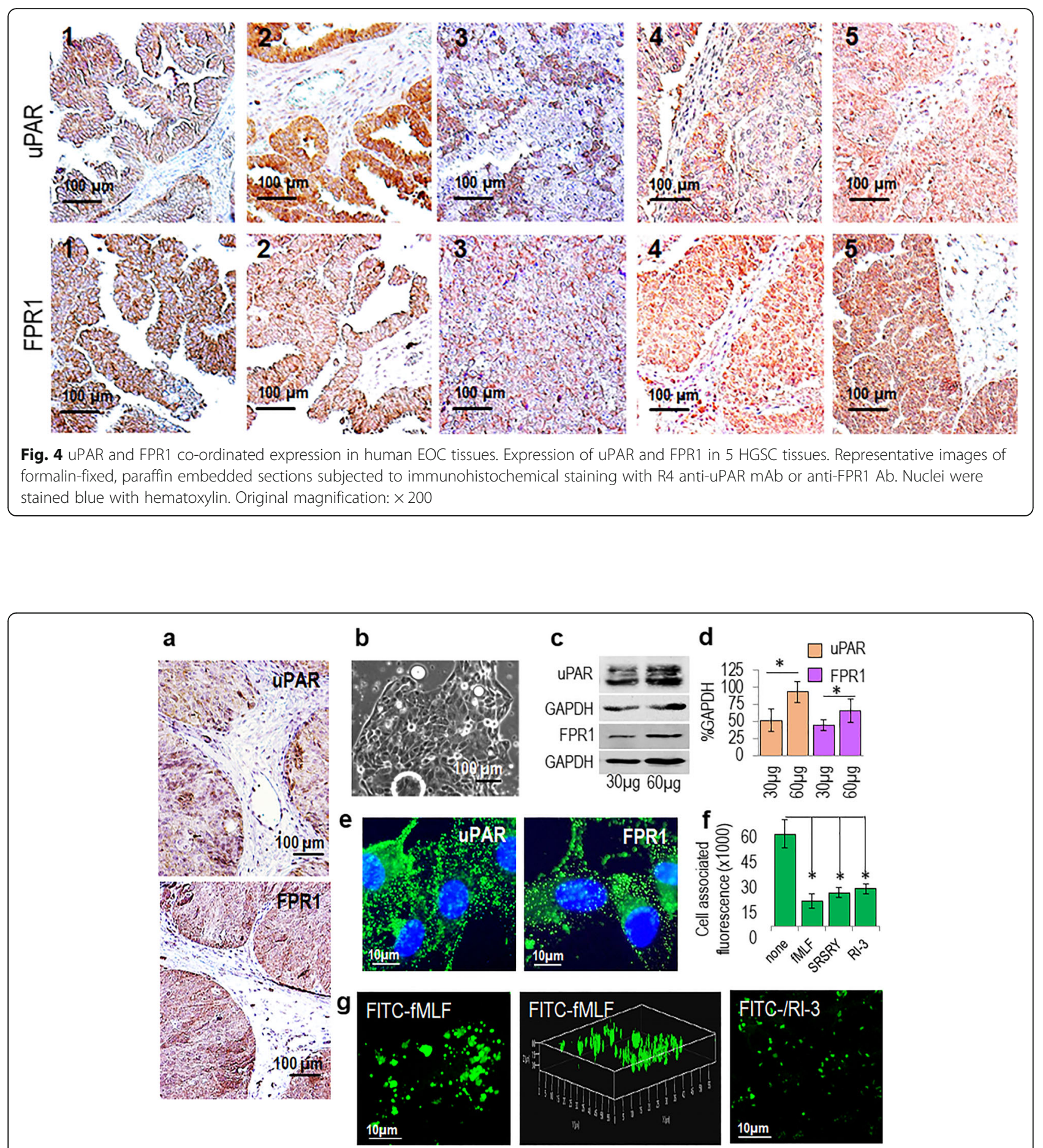
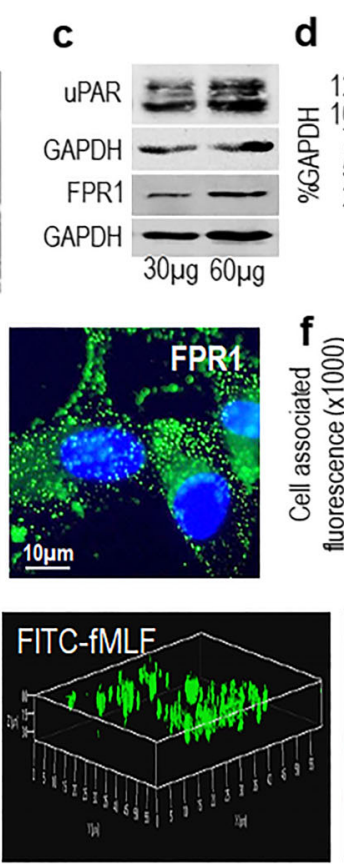

d
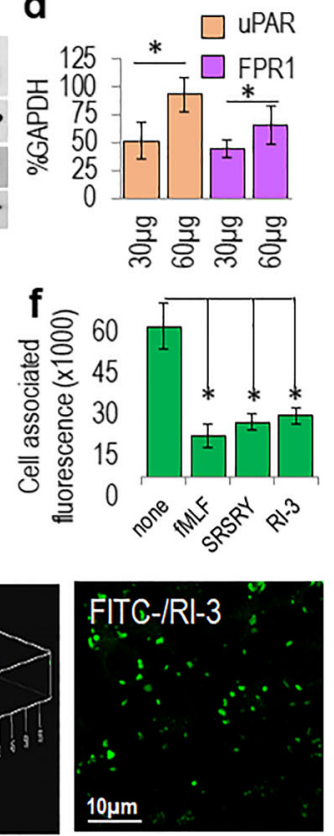

Fig. 5 Generation of a primary cell culture from a human high-grade serous ovarian cancer. a HGSG tissue (patient \# 5) processed for IHC analysis of UPAR and FPR1 expression on paraffin sections. Nuclei were stained blue with hematoxylin. Original magnifications: $\times 100$. b Primary EOC cells derived from the same HGSG tissue visualized by phase contrast microscopy. Original magnification: $\times 400$. c Western blotting of whole cell lysate from EOC cells with R4 anti-uPAR mAb, anti-FPR1 Ab, and anti-GAPDH Ab. d Bar graphs showing the average quantification of the uPAR/GAPDH and FPR1/GAPDH content from 3 independent experiments. Statistical significance with ${ }^{*} P<0.001$. e Images of human EOC cells immunostained with R4 anti-uPAR mAb or anti-FPR1 Ab and visualized by a fluorescence inverted microscope. Nuclei were stained blue with DAPI. Original magnification: 1000x. f Fluorescence associated to EOC cells pre-incubated with diluents (none), $100 \mathrm{nM}$ fMLF, $100 \mathrm{nM}$ SRSRY or $100 \mathrm{nM}$ RI-3, for $60 \mathrm{~min}$ at $4^{\circ} \mathrm{C}$, and then exposed to $10 \mathrm{nM}$ FITC-RI3 for additional $60 \mathrm{~min}$ at $4^{\circ} \mathrm{C}$. Data represent mean $+/-\mathrm{SD}$ from three experiments performed in triplicate with ${ }^{*} P<0.001$. g EOC cells exposed to $10 \mathrm{nM}$ FITC-fMLF or $10 \mathrm{nM}$ FITC-RI-3 for $30 \mathrm{~min}$ at $37^{\circ} \mathrm{C}$ and then visualized using a Zeiss 510 Meta LSM microscope in 2D (left) or 3D (right) projections. Original magnification: 630x 
slightly detectable in cells exposed to FITC-RI-3, indicating little or no internalization (Fig. 5g). These findings indicate that a uPAR/FPR1 crosstalk does occur on the surface of primary ovarian cancer cells and that, as already documented in FPR1 overexpressing rat basophilic leukaemia RBL-2H3/ETFR cells [38], RI-3 binds to FPR1 blocking its internalization and function.

\section{RI-3 inhibits primary EOC cell adhesion onto vitronectin and mesothelium invasion}

In order to assess whether the uPAR/FPR1 crosstalk dictates the capability of ovarian cancer cells to adhere onto $\mathrm{Vn}$ and mesothelium, a series of adhesion experiments was performed in the presence or the absence of $10 \mathrm{nM}$ RI-3. Like SKOV-3 cells, primary EOC cells from patient \#5 are able to adhere onto Vn, Fn, and Coll, although at a different extent (Fig. 6a) and the peptide RI-3 exclusively reduced cell adhesion onto Vn by $55 \%$ (Fig. 6a, b, c). When GFP-tagged EOC cells were seeded on a mesothelial cell monolayer in the presence/absence of $10 \mathrm{nM}$ RI-3, and cell associated fluorescence was measured after $5,10,20$, and $40 \mathrm{~min}$, we found that, similarly to SKOV-
3 cells, primary EOC cells adhere to mesothelium already after 5-10 min of incubation and that cell adhesion to mesothelium further increases over time. After 5, 10, 20, and $40 \mathrm{~min}, \mathrm{RI}-3$ caused a $72,51,47$, and $46 \%$, respectively, reduction of EOC cell adhesion onto mesothelium (Fig. 6d). Then, the ability of RI-3 to counteract mesothelial cell invasion by primary EOC cells was investigated as above described. An appreciable reduction of mesothelial cell monolayer integrity was achieved by EOC cells and RI-3, at $10 \mathrm{nM}$ concentration, reduced by about $80 \%$ the capability of EOC cells to cross the mesothelial cell monolayer (Fig. 6e-f). Collectively, these findings demonstrate that RI-3 greatly reduces the uPAR84-95-induced and FPR1-mediated adhesion onto and invasion through mesothelium of primary EOC cells. They also pinpoint the possibility that FPR1 may be considered a new biomarker predicting the ability of EOC cells to adhere and subsequently invade mesothelium.

\section{FPR1 expression in human EOC tissues}

In light of the results presented above, we analyzed the FPR1 expression profile in EOC tissues using a TMA
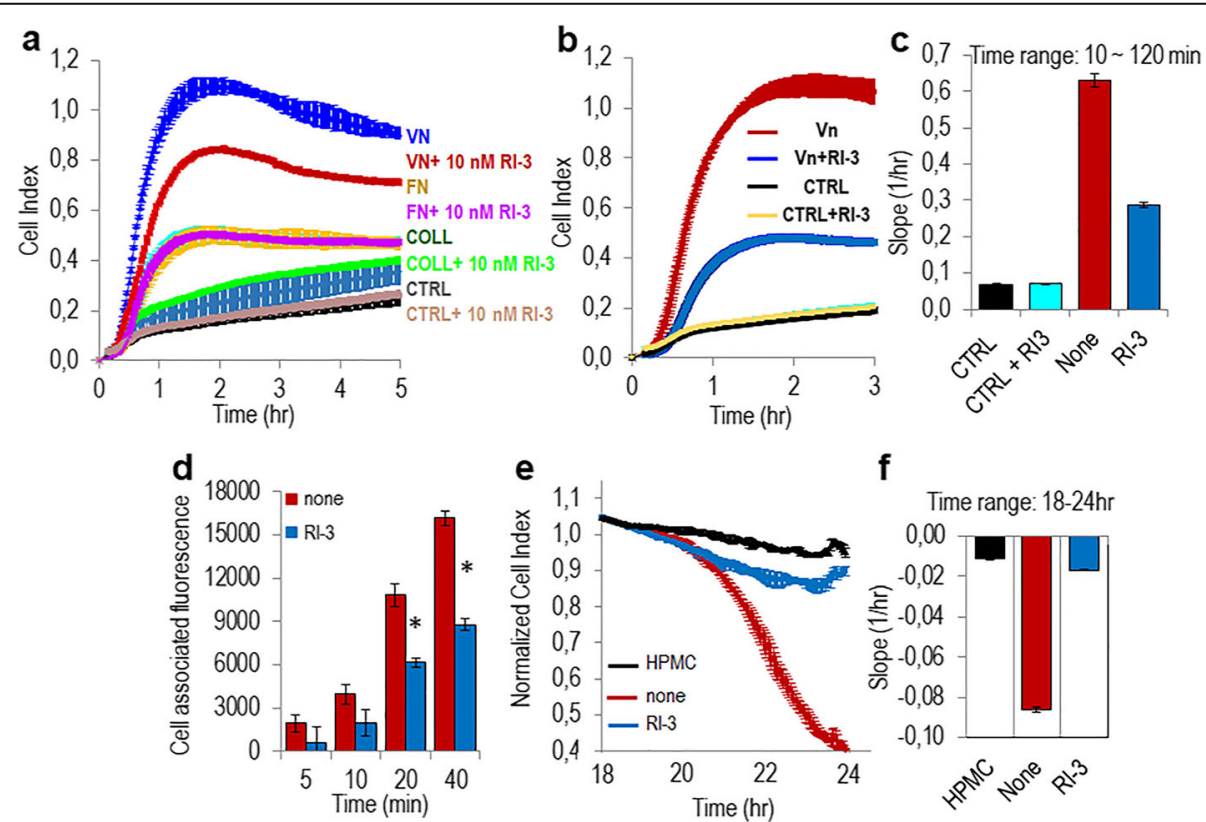

f

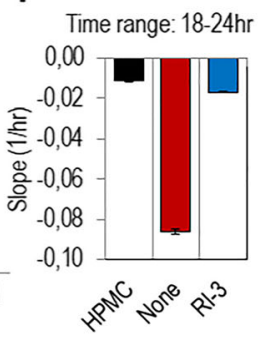

Fig. 6 Rl-3 prevents EOC cell adhesion and subsequent invasion of mesothelium. a Adhesion of primary EOC cells on E-plates coated with 1\%

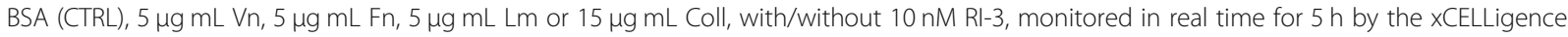
system. Data represent mean \pm SD from a quadruplicate experiment representative of 3 replicates. $\mathbf{b}-\mathbf{c}$ Adhesion of EOC cells onto $\mathrm{Vn}$ in the absence or presence of $10 \mathrm{nM} \mathrm{Rl-3,} \mathrm{monitored} \mathrm{in} \mathrm{real} \mathrm{time} \mathrm{for} 3 \mathrm{~h}$ by the xCELLigence system. Data represent mean \pm SD from a quadruplicate experiment representative of 3 replicates. Slopes represent the change rate of Cell Indexes generated in a 10-120 min time frame (c). d HPMCs were seeded in 24-well plates and allowed to attach for $20 \mathrm{~h}$ prior to seeding GFP-EOC cells suspended in complete medium plus diluents (none), or $10 \mathrm{nM} \mathrm{RI}-3$ at $37^{\circ} \mathrm{C}, 5 \% \mathrm{CO}_{2}$. At the indicated times, cell associated fluorescence was assessed by a fluorescence plate reader. Data represent means \pm SD of three independent experiments performed in triplicate with ${ }^{*} P<0.0001$ vs none. e-f Mesothelium-invasion by primary EOC cells. HPMCs $\left(5 \times 10^{3}\right.$ cells/well) were seeded in E-16-well plates in growth medium and allowed to adhere for $18 \mathrm{~h}$ to form a confluent monolayer. Then, EOC cells $\left(2 \times 10^{4}\right.$ cells/well) were seeded in growth medium plus/minus $10 \mathrm{nM} \mathrm{RI-3.} \mathrm{Cells} \mathrm{invasion} \mathrm{was} \mathrm{monitored} \mathrm{in} \mathrm{real-time}$ as changes in Cell Index due to breaking of the monolayer integrity (e). Slopes represent the change rate of Cell Indexes generated in a 18-24 $\mathrm{h}$ time frame $(\mathbf{f})$. Data represent mean \pm SD from a quadruplicate experiment representative of 3 replicates 
built with 37 EOC tissue samples. IHC highlighted variable expression of FPR1 both in the cytoplasm and on the plasma membrane of tumor cells (Fig. 7). FPR1 expression levels were evaluated by assessing either the percentages of positive tumor cells/TAM punch, either staining intensity of tumor cells, graded as faint (score 0), moderate (score 1), or intense (score 2). FPR1 scores were also correlated with the age, histotype, and FIGO stage. We found little FPR1 staining on plasma membranes and cytoplasm in $29.7 \%(n=11)$ of cases in which the percentage of FPR1 positive cells ranges between 0 and $10 \%$, with faint intensity. Conversely, the remaining $70.3 \%(n=26)$ of cases exhibited moderate or intense FPR1 expression in at least $80 \%$ of tumor cells (Table 2). Although no statistical evaluation was applicable for the lack of representativeness of LGSC, OCCC and mEOC cases, we observed that FPR1 is mainly expressed in HGSC tumors, and that $80 \%$ positive tumor cells observed in 20 out of 28 HGSC tissues. Remarkably, a high percentage of moderate or intense FPR1 staining of EOC cells seems to correlate with FIGO stage III (Table 2) as FPR1 protein increased in a stepwise fashion from FIGO stage I $(8 \%)$ to FIGO stage II $(21.6 \%)$ to FIGO stage III (37.8\%), suggesting a link between FPR1 abundancy to the malignant stages. No statistically significant correlation between the percentages of FPR1 positive cells in primary and matched metastatic tissues was found (Table 3). Interestingly, we observed that primary and matched metastases exhibit comparable expression levels of FPR1 with the exception of two cases in which FPR1 increases in metastatic lesions as compared to the primary ones and in a case in which metastatic cells are
FPR1-negative (Table 3). Also, differences in the FPR1 expression levels between 3 HGSC primary lesions and matching metastases recovered after chemotherapy, during the second-look laparotomy, were not significant. Although preliminary, these experiments detected for the first time FPR1 in human EOC tissues, suggesting FPR1 as a potential biomarker of aggressive EOC. Finally, the notion that uPAR overexpression associates with poor prognosis and unfavorable clinical outcome of EOC patients [17], together with the finding that most malignant EOC tissues express high levels of FPR1, may constitute the rationale for new therapeutic strategies that include inhibitors of the uPAR84-95/FPR1 interaction.

\section{Discussion}

Epithelial Ovarian carcinoma is deadliest gynecological malignancy, as the majority of patients with EOC are first diagnosed when peritoneal metastases have already formed. EOC cells detach from the primary cancer as single or clusters of tumor cells, carried by ascitic fluid and attach to mesothelium lining the peritoneal cavity, establishing metastasis [12, 13, 46]. Development of experimental models to study the mechanism of ovarian cancer metastasis is challenging, as conventional approaches used to study tumor diffusion do not apply to the peculiar EOC trans-coelomic dissemination. Herein, a novel technology that records in real-time impedance changes proportional to the number of invading cells was used to analyze mesothelial invasion. This model may allow to monitor the early events in peritoneal anchoring and invasion of tumor cells and could represent

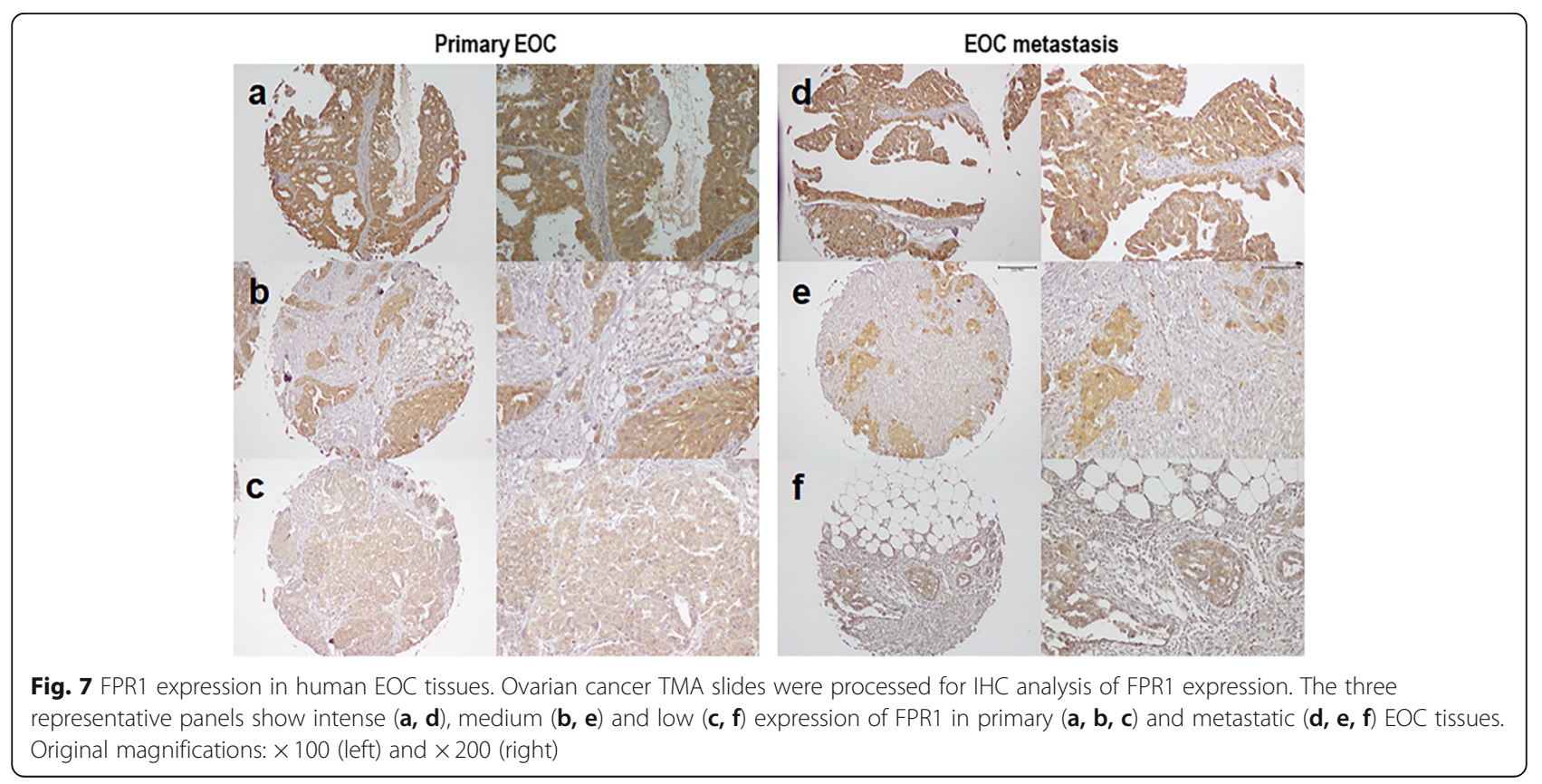


Table 2 Relationship between FPR1 expression and clinicopathological features of ovarian cancer tissues

\begin{tabular}{|c|c|c|c|c|c|c|c|c|}
\hline & & & \multicolumn{3}{|c|}{ FPR1 staining (\%) } & \multicolumn{3}{|c|}{ FPR1 staining (intensity) } \\
\hline & & & $\mathrm{Neg} \leq 10$ & Pos $\geq 80$ & $P$-value ${ }^{a}$ & 0 & 1 & 2 \\
\hline EOC tissues & n.cases & $37(100.0)$ & $11(29.7)$ & $26(70.3)$ & 0.391 & $11(29.7)$ & $17(45.9)$ & $9(24.3)$ \\
\hline \multirow[t]{2}{*}{ Age } & $\leq 50$ & $8(21.6)$ & $1(2.7)$ & $7(18.9)$ & 0.08 & $1(2.7)$ & $3(10.8)$ & $4(10.8)$ \\
\hline & $>50$ & $29(78.4)$ & $10(27.0)$ & $19(51.4)$ & 0.11 & $10(27.0)$ & $14(37.8)$ & $5(13.5)$ \\
\hline \multirow[t]{4}{*}{ Histotype } & LGSC & $3(8.1)$ & $1(2.7)$ & $2(5.4)$ & 0.612 & $1(2.7)$ & $2(5.4)$ & $0(0.0)$ \\
\hline & HGSC & $28(75.7)$ & $8(21.6)$ & $20(54.1)$ & & $8(21.6)$ & $13(35.1)$ & $7(18.9)$ \\
\hline & OCCC & $5(13.5)$ & $1(2.7)$ & $4(10.8)$ & & $1(2.7)$ & $2(5.4)$ & $2(5.4)$ \\
\hline & $\mathrm{mEOC}$ & $1(2.7)$ & $1(2.7)$ & $0(0.0)$ & & $1(2.7)$ & $0(0.0)$ & $0(0.0)$ \\
\hline \multirow[t]{4}{*}{ FIGO } & 1 & $6(16.2)$ & $3(8.1)$ & $3(8.1)$ & 0.42 & $3(8.1)$ & $2(5.4)$ & $1(2.7)$ \\
\hline & $\|$ & $9(24.3)$ & $1(2.7)$ & $8(21.6)$ & & $1(2.7)$ & $4(10.8)$ & $4(10.8)$ \\
\hline & III & $21(56.8)$ & $7(18.9)$ & $14(37.8)$ & & $7(18.9)$ & $10(27.0)$ & $4(10.8)$ \\
\hline & IV & $1(2.7)$ & $0(0.0)$ & $1(2.7)$ & & $0(0.0)$ & $1(2.7)$ & $0(0.0)$ \\
\hline
\end{tabular}

a $P$ - value calculated using Pearson's Chi-square $\left(\mathrm{X}^{2}\right)$ test

a suitable model to test potential anti-invasive therapeutics.

In this study, we provide evidence that EOC adhesion to the mesothelium and subsequent spreading could be blocked by the recently identified RI-3 peptide interfering with the interaction of UPAR with FPR1, both regulators of cell adhesion and invasion [36, 38]. In agreement with the notion that vitronectin is the main mesothelium-associated ligand [46-50], SKOV-3 ovarian

Table 3 FPR1 expression in primary and metastatic ovarian cancer tissues

\begin{tabular}{|c|c|c|c|c|c|}
\hline \multirow[t]{2}{*}{ HISTOTYPE } & \multirow[t]{2}{*}{ FIGO } & \multicolumn{2}{|l|}{$P^{a}$} & \multicolumn{2}{|l|}{$M^{b}$} \\
\hline & & $\geq 80 \%$ staining & intensity & $\geq 80 \%$ staining & intensity \\
\hline LGSC & $\|$ & pos & 1 & pos & 2 \\
\hline LGSC & III & pos & 1 & pos & 1 \\
\hline HGSC & III & pos & 1 & pos & 1 \\
\hline HGSC & III & pos & 1 & pos & 1 \\
\hline HGSC & III & pos & 1 & pos & 1 \\
\hline HGSC & IV & pos & 1 & pos & 1 \\
\hline HGSC & III & pos & 1 & pos & 1 \\
\hline HGSC & $\|$ & pos & 2 & pos & 1 \\
\hline HGSC & III & pos & 2 & pos & 2 \\
\hline HGSC & $\|$ & pos & 2 & pos & 1 \\
\hline HGSC & III & neg & 0 & pos & 1 \\
\hline HGSC & III & neg & 0 & pos & 1 \\
\hline HGSC & III & pos & 1 & neg & 0 \\
\hline HGSC & III & neg & 0 & neg & 0 \\
\hline OCCC & $\|$ & pos & 2 & pos & 2 \\
\hline OCcC & III & pos & 1 & pos & 1 \\
\hline
\end{tabular}

aprimary EOC

${ }^{\mathrm{b}}$ Intra-abdominal EOC metastases cancer and primary EOC cells, the last derived from a human HGSC tissue sample, markedly adhere to $\mathrm{Vn}$ matrices as well as to a re-constructed mesothelial layer. Under these conditions, cell adhesion onto $\mathrm{Vn}$ is uPAR84-95-dependent and FPR1-mediated for the following reasons; i) cell adhesion to $\mathrm{Vn}$ decreases to the basal level in the presence of anti-uPAR84-95 Abs, but not by $\mathrm{R} 3$ anti-uPAR $\mathrm{mAb}$ which does not recognizes the uPAR84-95 sequence, being directed to the D1 uPAR domain; iì) cells fail to adhere onto $V n$ when desensitized with an excess of AMLF or SRSRY that allow FPR1 to internalize thereby making it unavailable on the cell membrane [38]; ìì) RI-3 peptide blocking FPR1 anchored on cell membrane and unable to signal [38], abrogates EOC cell adhesion onto Vn; ìv) human EOC cells lacking of both uPAR and FPR1 poorly adhere onto Vn.

Among the signaling pathways active to control metastatic spread of cancers are the members of activator protein-1 (AP-1) family transcription factors, including c-Fos [51]. This transcriptional activator binds to AP-1 motifs localized also in the uPA and uPAR promoter regions, upregulating their mRNA synthesis [14].. When expressed on cell surface, UPAR associates with various integrins in large molecular complexes [52], and regulates integrin function directly, by interacting with the alpha chain of integrin, possibly, through "lateral" interactions [53, 54], or indirectly, through its UPAR 8495 sequence that has been shown to trigger integrin $\alpha v \beta 3$ activation with an inside-out mechanism, upon binding to FPR1 [26]. In 2012, we reported that the substitution of the Ser90 in the uPAR84-95 sequence generates a dominant-negative variant of uPAR that prevents agonist-triggered FPR1 activation and internalization, decreases binding and adhesion to $\mathrm{Vn}$, and inhibits uPAR/vitronectin receptor association [55]. As a 
working model for RI-3-dependent inhibition of EOC cell adhesion onto $\mathrm{Vn}$, we propose that the peptide blocks uPAR-triggered FPR1 activation, which ultimately impairs $\alpha v \beta 3$ activation (Fig. 8). Since alpha-v integrin receptor is known to be involved in ovarian cell adhesion to mesothelium [56] it will be interesting to investigate whether $\alpha v \beta 3$ integrin inhibitors may synergize with RI-3 inhibitor in reducing mesothelial invasion of EOC cells. Furthermore, since uPA/uPAR complexes regulate entering of cancer stem cells a dormant state when unable to establish integrin-mediated interactions, we plan to investigate whether FPR1 expression/function is involved in this process [57].

To the best of our knowledge, no data are available in literature on the FPR1 expression in EOC cells. Here, we show for the first time a diffuse moderate/intense staining of FPR 1 in the $70 \%$ of examined EOC tissue samples, showing high-level expression of this receptor in most tissue samples. In this respect, we plan to extend the number of cases to evaluate the power of FPR1 as a negative prognostic marker, as well as the possible correlation between FPR1 expression levels, histotype, and
FIGO staging. For EOC patients, the risk of relapse is high, and most of them develop platinum-resistant progressive disease, which restricts available therapeutic options. Emerging data suggest that the cell-signaling activity of uPAR may allow cancer cells to "escape" from the cytotoxic effects of targeted anticancer drugs [58]. It will be interesting to analyze whether the acquired resistance to chemotherapy of EOC patients correlates with changes in the uPAR and/or FPR1 expression levels. Intriguingly, in a single HGSC case, FPR1 staining of ciliated epithelium from fallopian tubes adjacent to neoplastic areas was observed. Because it has been reported that fallopian tube epithelium gives rise to serous ovarian cancers [59-61], we are planning to analyze indepth the expression levels of FPR1 in areas adjacent to the EOC tissues.

To date, most therapeutics strategies targeting uPAR do not shown robust anti-tumor activity $[62,63]$. On the other hand, despite a variety of natural and synthetic compounds that interfere with FPR1-dependent pathways antagonizing FPR1functions have been described $[64,65]$, the majority had off-target effects, discouraging

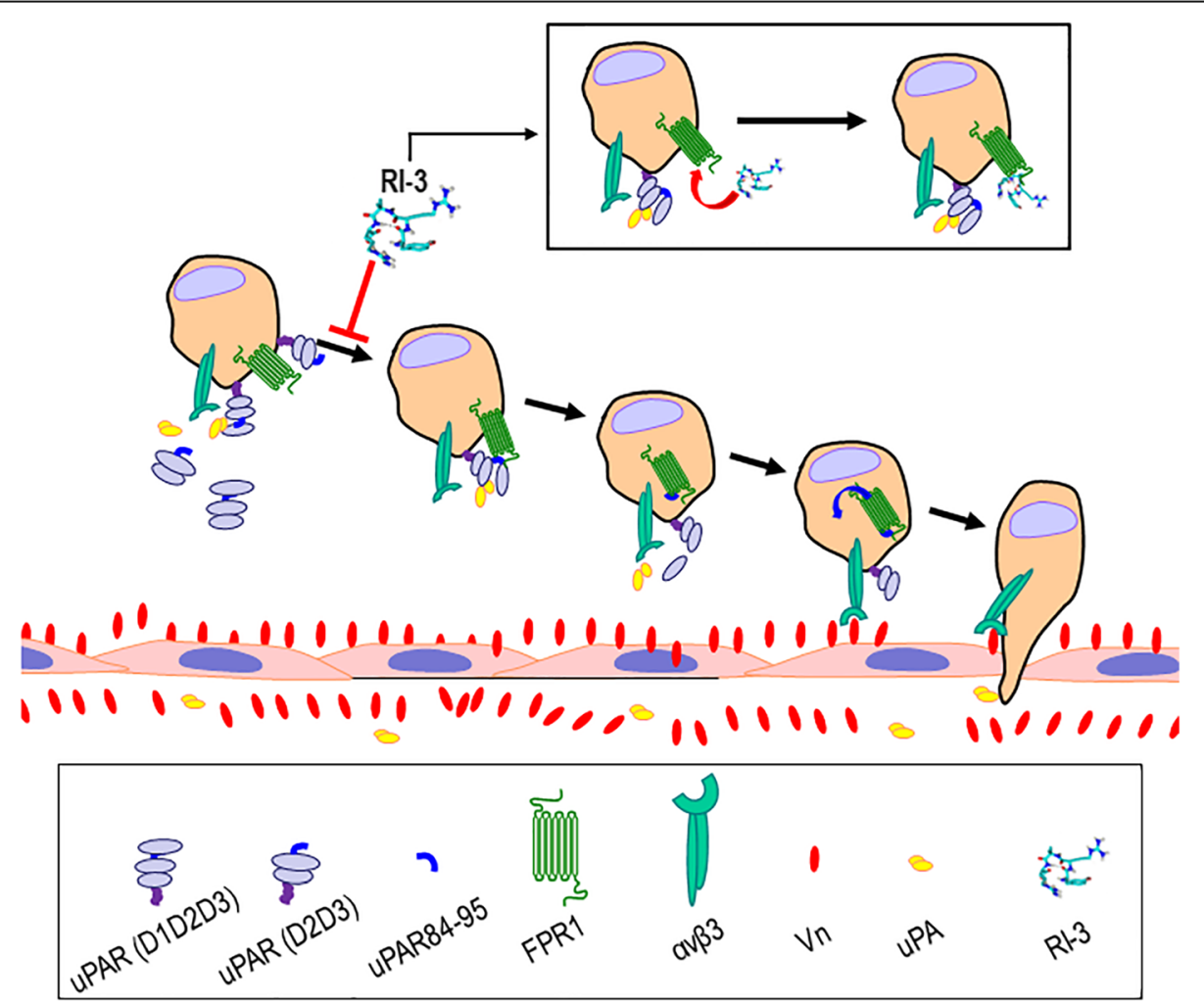

Fig. 8 Schematic diagram of proposed mechanism of Rl-3 inhibitory effects on EOC cell adhesion. After detachment from the primary tumor, EOC cells float in the peritoneal fluid. EOC cells able to adhere to mesothelial ECM components via integrins may penetrate mesothelial cell layers. Intact UPAR or UPAR-derived fragments containing the 84-95 sequence that are expressed on EOC cell surface or may be released in the ascitic fluid, bind to FPR1 generating a cascade of events. Once engaged, FPR1 internalizes, triggering av $\beta 3$ vitronectin receptor activation which, in turn, allows EOC cells to adhere onto mesothelial Vn. Subsequently, proteases within the mesothelial milieu allow EOC cells to invade the mesothelial cell layer where they proliferate and form metastases. This process may be counteracted by nanomolar concentrations of RI-3 peptide, blocking the assembly of UPAR/FPR1 complexes 
their clinical development. In this contest, the selective impairment of uPAR-mediated FPR1 triggered signaling by RI-3 is expected does not affect other functions regulated by FPR1. Indeed RI-3 does not affect cell proliferation and was well tolerated in vivo when administered to mice with no visible side-effects and no change of body weight versus vehicle-treated animals [36]. Now we found that RI-3 not only prevents EOC cell adhesion to mesothelium but also dramatically decreases the ability of EOC cells to cross mesothelial cell monolayers. Although we not yet studied the efficacy of RI-3 in preventing EOC attachment to mesothelium and subsequent invasion in animal models, our findings suggest that RI-3 may be considered as a valid prototype for the development of new therapies which, combined with conventional chemotherapy, should counteract intraabdominal dissemination of EOC cells.

\section{Conclusions}

Collectively, our findings identify FPR1 as novel, valuable, marker for predicting the propensity of EOC cells to adhere and subsequently invade mesothelium. Furthermore, they suggest FPR1 as a new therapeutic target to be blocked by inhibitors of the uPAR84-95/FPR1 crosstalk for the treatment of metastatic ovarian cancer.

\section{Supplementary information}

Supplementary information accompanies this paper at https://doi.org/10. 1186/s13046-019-1465-8.

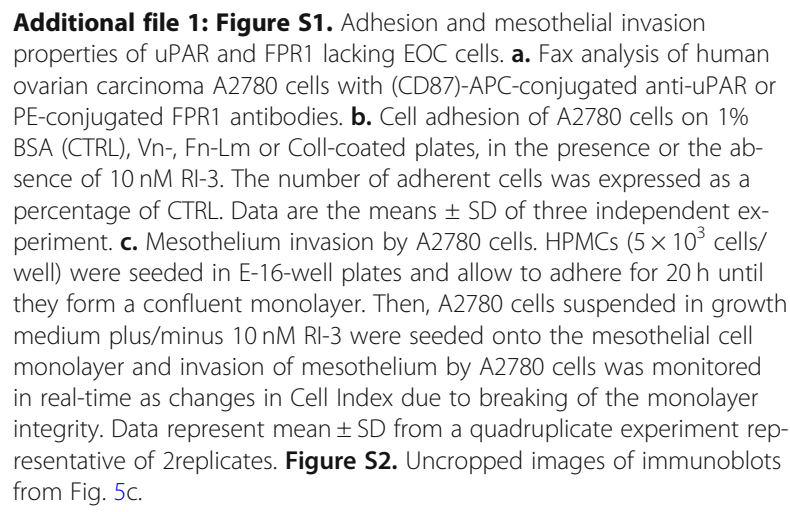

\section{Abbreviations \\ ECM: Extracellular matrix; EOC: Epithelial ovarian cancer; FBS: Foetal bovine serum; fMLF: N-formyl-Met-Leu-Phe; FPR1: Formyl-peptide receptor type 1; HGSC: High-grade serous carcinoma; HPMC: Human peritoneal mesothelial cell; IHC: Immunohistochemistry; LGSC: Low-grade serous carcinoma; mEOC: Mucinous ovarian carcinoma; NRS: Normal rabbit serum; OCCC: Clear cell carcinoma; PBS: Phosphate-buffered saline; TBS: Tris buffered saline; TMA: Tissue microarray; uPA: Urokinase Plasminogen Activator; UPAR: Urokinase Receptor}

\section{Acknowledgements}

The authors are grateful to Dr. Gioconda Di Carluccio (Istituto Nazionale Tumori IRCCS "Fondazione G. Pascale") for her technical assistance. We thank
G. Hoyer-Hansen (Finsen Institute, Copenhagen, Denmark) who kindly provided the R3 and R4 anti-uPAR monoclonal antibodies.

\section{Authors' contributions}

MVC and SL conceived, and wrote the manuscript. MM and GB designed experiments. MM, GB VG, CR, SS, GS, MLM, and MSR performed the experiments and analyzed data. SG and CS provided human tissues and analyzed clinical data. GC and MPS supervised and finalized the project. All authors reviewed the manuscript. All authors read and approved the final manuscript.

\section{Funding}

This work was supported by AIRC (Associazione Italiana per la Ricerca sul Cancro, projects 14225, by Regione Campania POR SATIN, by Italian Ministry of Health RF-2010-2316780 and by Italian Ministry of Health, "Ricerca Corrente" project \#2611752. Maria Serena Roca is supported by an AIRC Fellowship (AIRC id. 21113).

\section{Availability of data and materials}

All data generated or analyzed during this study are included in this published article and its supplementary information file. Further details are available from the corresponding author on reasonable request.

\section{Ethics approval and consent to participate}

All experimental protocols were performed in accordance with guidelines of the Istituto Nazionale Tumori "Fondazione G. Pascale"-IRCCS (Quality System n. LRC 6019486/QMS/U/IT- 2015 certificated in conformity with UNI EN ISO 9001:2008). The research work with primary cell lines and EOC tissues has been approved by Institutional Ethical Committee of Istituto Nazionale Tumori "Fondazione G. Pascale"-IRCCS, Naples, Italy (protocol 258/18, December 2018).

\section{Consent for publication}

All authors give consent for the publication of the manuscript.

\section{Competing interests}

The authors declare that they have no competing interests.

\section{Author details}

${ }^{1}$ Neoplastic Progression Unit, Istituto Nazionale Tumori IRCCS 'Fondazione G. Pascale', Via M.Semmola, 80131 Naples, Italy. ${ }^{2}$ University of Campania "Luigi Vanvitelli", Naples, Italy. ${ }^{3}$ Pathology Unit, Istituto Nazionale Tumori IRCCS 'Fondazione G. Pascale', Naples, Italy. “University 'Parthenope', Naples, Italy. ${ }^{5}$ Gynecologic Oncology, Istituto Nazionale Tumori IRCCS 'Fondazione G. Pascale', Naples, Italy. 'Experimental Pharmacology Unit, Istituto Nazionale Tumori IRCCS 'Fondazione G. Pascale', Naples, Italy. 'Institute of Genetics and Biophysics, National Research Council, Naples, Italy. ${ }^{8}$ Istituto Nazionale Tumori IRCCS "Regina Elena", Rome, Italy.

Received: 31 July 2019 Accepted: 21 October 2019

Published online: 08 November 2019

\section{References}

1. Reid BM, Permuth JB, Sellers TA. Epidemiology of ovarian cancer: a review. Cancer Biol Med. 2017:14:9-32

2. Arnold M, Rutherford MJ, Bardot A, Ferlay J, Andersson TM, Myklebust TA, et al. Progress in cancer survival, mortality, and incidence in seven highincome countries 1995-2014 (ICBP SURVMARK-2): a population-based study. Lancet Oncol; 2019. https://doi.org/10.1016/S1470-2045(19)30456-5. In press.

3. Bray F, Ferlay J, Soerjomataram I, Siegel RL, Torre LA, Jemal A. Global cancer statistics 2018: GLOBOCAN estimates of incidence and mortality worldwide for 36 cancers in 185 countries. CA Cancer J Clin. 2018;68:394-424.

4. Siegel RL, Miller KD, Jemal A. Cancer statistics, 2015: Cancer statistics, 2015. CA Cancer J Clin. 2015;65:5-29.

5. Verhaak RGW, Tamayo P, Yang J-Y, Hubbard D, Zhang H, Creighton CJ, et al. Prognostically relevant gene signatures of high-grade serous ovarian carcinoma. J Clin Invest. 2013;123:517-25.

6. Riester M, Wei W, Waldron L, Culhane AC, Trippa L, Oliva E, et al. Risk prediction for late-stage ovarian cancer by meta-analysis of 1525 patient samples. J Natl Cancer Inst. 2014;106(5). https://doi.org/10.1093/jnci/dju048. PMID:24700803 
7. Konecny GE, Wang C, Hamidi H, Winterhoff B, Kalli KR, Dering J, et al. Prognostic and therapeutic relevance of molecular subtypes in high-grade serous ovarian cancer. J Natl Cancer Inst. 2014;106(10). https://doi.org/10. 1093/jnci/dju249. PMID:25269487

8. Bagnoli M, Canevari S, Califano D, Losito S, Maio MD, Raspagliesi F, et al. Development and validation of a microRNA-based signature (MiROvaR) to predict early relapse or progression of epithelial ovarian cancer: a cohort study. Lancet Oncol. 2016;17:1137-46.

9. Petrillo M, Marchetti C, De Leo R, Musella A, Capoluongo E, Paris I, et al. BRCA mutational status, initial disease presentation, and clinical outcome in high-grade serous advanced ovarian cancer: a multicenter study. Am J Obstet Gynecol. 2017;217:334.e1-9.

10. Jayson GC, Kohn EC, Kitchener HC, Ledermann JA. Ovarian cancer. Lancet. 2014;384:1376-88.

11. Shield K, Ackland ML, Ahmed N, Rice GE. Multicellular spheroids in ovarian cancer metastases: biology and pathology. Gynecol Oncol. 2009;113:143-8.

12. Sodek KL, Murphy KJ, Brown TJ, Ringuette MJ. Cell-cell and cell-matrix dynamics in intraperitoneal cancer metastasis. Cancer Metastasis Rev. 2012; 31:397-414.

13. Lengyel E, Burdette JE, Kenny HA, Matei D, Pilrose J, Haluska P, et al. Epithelial ovarian cancer experimental models. Oncogene. 2014;33:3619-33.

14. Carriero MV, Stoppelli MP. The urokinase-type plasminogen activator and the generation of inhibitors of urokinase activity and signaling. Curr Pharm Des. 2011;17:1944-61.

15. Al-Hassan NN, Behzadian A, Caldwell R, Ivanova VS, Syed V, Motamed K, et al. Differential roles of uPAR in peritoneal ovarian Carcinomatosis. Neoplasia. 2012;14:259-70.

16. Leandersson P, Kalapotharakos G, Henic E, Borgfeldt H, Petzold M, HøyerHansen G, Borgfeldt C. A biomarker panel increases the diagnostic performance for epithelial ovarian cancer type I and II in young women. Anticancer Res. 2016;36(3):957-65.

17. Henić E, Borgfeldt C, Christensen IJ, Casslén B, Høyer-Hansen G. Cleaved forms of the Urokinase plasminogen activator receptor in plasma have diagnostic potential and predict postoperative survival in patients with ovarian cancer. Clin Cancer Res. 2008;14:5785-93.

18. Jacobsen $B$, Ploug $M$. The urokinase receptor and its structural homologue C4.4A in human cancer: expression, prognosis and pharmacological inhibition. Curr Med Chem. 2008;15:2559-73.

19. Sidenius N, Blasi F. The urokinase plasminogen activator system in cancer: recent advances and implication for prognosis and therapy. Cancer Metastasis Rev. 2003;22:205-22.

20. Høyer-Hansen G, Rønne E, Solberg H, Behrendt N, Ploug M, Lund LR, et al. Urokinase plasminogen activator cleaves its cell surface receptor releasing the ligand-binding domain. J Biol Chem. 1992;267:18224-9.

21. Lund IK, Illemann M, Thurison T, Christensen IJ, Høyer-Hansen G. UPAR as anticancer target: evaluation of biomarker potential, histological localization, and antibody-based therapy. Curr Drug Targets. 2011;12:1744-60.

22. Yuan C, Huang M. Does the urokinase receptor exist in a latent form? Cell Mol Life Sci. 2007:64:1033-7.

23. Gårdsvoll H, Jacobsen B, Kriegbaum MC, Behrendt N, Engelholm L, Østergaard S, et al. Conformational regulation of urokinase receptor function: impact of receptor occupancy and epitope-mapped monoclonal antibodies on lamellipodia induction. J Biol Chem. 2011;286:33544-56.

24. Fazioli F, Resnati M, Sidenius N, Higashimoto Y, Appella E, Blasi F. A urokinase-sensitive region of the human urokinase receptor is responsible for its chemotactic activity. EMBO J. 1997;16:7279-86.

25. Resnati M, Pallavicini I, Wang JM, Oppenheim J, Serhan CN, Romano M, et al. The fibrinolytic receptor for urokinase activates the $\mathrm{G}$ protein-coupled chemotactic receptor FPRL1/LXA4R. Proc Natl Acad Sci U S A. 2002;99:1359-64.

26. Gargiulo L, Longanesi-Cattani I, Bifulco K, Franco P, Raiola R, Campiglia P, et al. Cross-talk between $\mathrm{FMLP}$ and vitronectin receptors triggered by urokinase receptor-derived SRSRY peptide. J Biol Chem. 2005;280:25225-32.

27. Bifulco K, Votta G, Ingangi V, Carluccio GD, Rea D, Losito S, et al. Urokinase receptor promotes ovarian cancer cell dissemination through its 84-95 sequence. Oncotarget. 2014;5:4154-69.

28. Bifulco K, Longanesi-Cattani I, Gala M, DI Carluccio G, Masucci MT, Pavone V, et al. The soluble form of urokinase receptor promotes angiogenesis through its $\mathrm{Ser}^{88}$-Arg-Ser-Arg-Tyr ${ }^{92}$ chemotactic sequence. J Thromb Haemost. 2010;8:2789-99.

29. Ingangi V, Bifulco K, Yousif AM, Ragone C, Motti ML, Rea D, et al. The urokinase receptor-derived cyclic peptide [SRSRY] suppresses neovascularization and intravasation of osteosarcoma and chondrosarcoma cells. Oncotarget. 2016;7:54474-87.

30. Panaro MA, Acquafredda A, Sisto M, Lisi S, Maffione AB, Mitolo V. Biological role of the N-Formyl peptide receptors. Immunopharmacol Immunotoxicol. 2006;28:103-27.

31. Zhou Y, Bian X, Le Y, Gong W, Hu J, Zhang X, et al. Formylpeptide receptor FPR and the rapid growth of malignant human gliomas. J Natl Cancer Inst. 2005;97:823-35.

32. Bifulco K, Longanesi-Cattani I, Gargiulo L, Maglio O, Cataldi M, De Rosa M, et al. An urokinase receptor antagonist that inhibits cell migration by blocking the formyl peptide receptor. FEBS Lett. 2008:582:1141-6.

33. Carriero MV, Longanesi-Cattani I, Bifulco K, Maglio O, Lista L, Barbieri A, et al. Structure-based design of an urokinase-type plasminogen activator receptor-derived peptide inhibiting cell migration and lung metastasis. Mol Cancer Ther. 2009:8:2708-17.

34. Bifulco K, Longanesi-Cattani I, Liguori E, Arra C, Rea D, Masucci MT, et al. A Urokinase receptor-derived peptide inhibiting VEGF-dependent directional migration and vascular sprouting. Mol Cancer Ther. 2013;12:1981-93.

35. Carriero MV, Bifulco K, Minopoli M, Lista L, Maglio O, Mele L, et al. UPARANT: a urokinase receptor-derived peptide inhibitor of VEGF-driven angiogenesis with enhanced stability and in vitro and in vivo potency. Mol Cancer Ther. 2014;13:1092-104

36. Carriero MV, Bifulco K, Ingangi V, Costantini S, Botti G, Ragone C, et al. Retro-inverso Urokinase receptor antagonists for the treatment of metastatic sarcomas. Sci Rep. 2017;7:1312.

37. Ragone C, Minopoli M, Ingangi V, Botti G, Fratangelo F, Pessi A, et al. Targeting the cross-talk between Urokinase receptor and Formyl peptide receptor type 1 to prevent invasion and trans-endothelial migration of melanoma cells. J Exp Clin Cancer Res. 2017;36:180.

38. Minopoli M, Polo A, Ragone C, Ingangi V, Ciliberto G, Pessi A, Sarno S, Budillon A, Costantini S, Carriero MV. Structure-function relationship of an Urokinase Receptor-derived peptide which inhibits the Formyl Peptide Receptor type 1 activity. Sci Rep. 2019;9(1):12169.

39. Bifulco K, De Chiara A, Fazioli F, Longanesi-Cattani I, Cantelmo AR, Tirino V, et al. Cell invasiveness in sarcomas: a possibly useful clinical correlation. Tumori. 2008:94:505-10.

40. Carriero MV, Del Vecchio S, Franco P, Potena MI, Chiaradonna F, Botti G, et al. Vitronectin binding to urokinase receptor in human breast cancer. Clin Cancer Res. 1997;3:1299-308.

41. Kurman RJ, Carcangiu ML, Herrington CS, Young RH. WHO Classification of Tumours of Female Reproductive Organs, vol. 6. 4th ed: 2014. 9789283244875. IARC. http.// publications.iarc.fr/Book-And-Report-Series/Who-larc-Classification-Of-Tumours

42. Cantile M, Scognamiglio G, La Sala L, La Mantia E, Scaramuzza V, Valentino $\mathrm{E}$, et al. Aberrant expression of posterior HOX genes in well differentiated Histotypes of thyroid cancers. Int J Mol Sci. 2013;14:21727-40.

43. Botti G, Scognamiglio G, Cantile M. PD-L1 Immunohistochemical Detection in Tumor Cells and Tumor Microenvironment: Main Considerations on the Use of Tissue Micro Arrays. Int J Mol Sci. 2016;17(7). https://doi.org/10.3390/ ijms17071046. PMID:27376268

44. Gemperle C, Schmid M, Herova M, Marti-Jaun J, Wuest SJA, Loretz C, et al. Regulation of the Formyl peptide receptor 1 (FPR1) gene in primary human macrophages. PLoS One. 2012;7(11):e50195.

45. Ahmed N, Riley C, Oliva K, Rice G, Quinn M. Ascites induces modulation of a6 $\beta 1$ integrin and urokinase plasminogen activator receptor expression and associated functions in ovarian carcinoma. Br J Cancer. 2005;92:1475-85.

46. Kenny HA, Kaur S, Coussens LM, Lengyel E. The initial steps of ovarian cancer cell metastasis are mediated by MMP-2 cleavage of vitronectin and fibronectin. J Clin Invest. 2008;118:1367-79.

47. Heyman L, Kellouche S, Fernandes J, Dutoit S, Poulain L, Carreiras F. Vitronectin and its receptors partly mediate adhesion of ovarian cancer cells to peritoneal mesothelium in vitro. TBI. 2008:29:231-44.

48. Heyman L, Leroy-Dudal J, Fernandes J, Seyer D, Dutoit S, Carreiras F. Mesothelial vitronectin stimulates migration of ovarian cancer cells. Cell Biol Int. 2010;34:493-502

49. Sluiter N, de Cuba E, Kwakman R, Kazemier G, Meijer G, te Velde EA. Adhesion molecules in peritoneal dissemination: function, prognostic relevance and therapeutic options. Clin Exp Metastasis. 2016:33:401-16.

50. Gabriela Schneider, Malwina Suszynska, Sham Kakar, Mariusz Z Ratajczak Vitronectin in the ascites of human ovarian carcinoma acts as a potent chemoattractant for ovarian carcinoma: Implication for metastasis by cancer 
stem cells. J Cancer Stem Cell Res. 2016;4:e1005. https://doi.org/10.14343/ JCSCR.2016.4e1005. PMCID: PMC5461934

51. Muhammad N, Bhattacharya S, Steele R, Phillips N, Ray RB. Involvement of c-Fos in the promotion of cancer stem-like cell properties in head and neck squamous cell carcinoma. Clin Cancer Res. 2017;23:3120-8.

52. Bohuslav J, Horejsí V, Hansmann C, Stöckl J, Weidle UH, Majdic O, et al. Urokinase plasminogen activator receptor, beta 2-integrins, and Src-kinases within a single receptor complex of human monocytes. J Exp Med. 1995; 181:1381-90.

53. Carriero MV, Del Vecchio S, Capozzoli M, Franco P, Fontana L, Zannetti A, et al. Urokinase receptor interacts with alpha(v)beta5 vitronectin receptor, promoting urokinase-dependent cell migration in breast cancer. Cancer Res. 1999:59:5307-14.

54. Smith HW, Marshall CJ. Regulation of cell signalling by UPAR. Nat Rev Mol Cell Biol. 2010:11:23-36.

55. Bifulco K, Longanesi-Cattani I, Franco P, Pavone V, Mugione P, Di Carluccio $\mathrm{G}$, et al. Single amino acid substitutions in the chemotactic sequence of urokinase receptor modulate cell migration and invasion. PLoS One. 2012;: $: 44806$

56. Wang Y, Liu J, Lin B, Wang C, Li Q, Liu S, et al. Study on the expression and clinical significances of Lewis y antigen and integrin av, $\beta 3$ in epithelial ovarian tumors. Int J Mol Sci. 2011;12:3409-21.

57. Ingangi V, Minopoli M, Ragone C, Motti ML, Carriero MV. Role of microenvironment on the fate of disseminating cancer stem cells. Front Oncol. 2019;9:82

58. Steven L. Gonias, Jingiing Hu. Urokinase receptor and resistance to targeted anticancer agents. Front Pharmacol. 2015;6:154. https://doi.org/10.3389/ fphar.2015.00154. PMCID: PMC451554

59. Kurman RJ, Shih I-M. The origin and pathogenesis of epithelial ovarian cancer- a proposed unifying theory. Am J Surg Pathol. 2010;34:433-43.

60. Karst AM, Levanon K, Drapkin R. Modeling high-grade serous ovarian carcinogenesis from the fallopian tube. PNAS. 2011;108:7547-52.

61. George SHL, Garcia R, Slomovitz BM. Ovarian cancer: the fallopian tube as the site of origin and opportunities for prevention. Front Oncol. 2016;6:108

62. O'Halloran TV, Ahn R, Hankins P, Swindell E, Mazar AP. The many spaces of UPAR: delivery of Theranostic agents and Nanobins to multiple tumor compartments through a single target. Theranostics. 2013:3:496-506.

63. Mahmood N, Mihalcioiu C, Rabbani SA. Multifaceted role of the Urokinasetype plasminogen activator (UPA) and its receptor (UPAR): diagnostic, prognostic, and therapeutic applications. Front Oncol. 2018;8:24.

64. Schepetkin IA, Khlebnikov Al, Kirpotina LN, Quinn MT. Antagonism of human formyl peptide receptor 1 with natural compounds and their synthetic derivatives. Int Immunopharmacol. 2016;37:43-58.

65. Hui-Qiong He, Richard D. Ye. The Formyl Peptide Receptors: Diversity of Ligands and Mechanism for Recognition. Molecules. 2017;22(3):455. https:// doi.org/10.3390/molecules22030455. PMCID: PMC6155412

\section{Publisher's Note}

Springer Nature remains neutral with regard to jurisdictional claims in published maps and institutional affiliations.

Ready to submit your research? Choose BMC and benefit from:

- fast, convenient online submission

- thorough peer review by experienced researchers in your field

- rapid publication on acceptance

- support for research data, including large and complex data types

- gold Open Access which fosters wider collaboration and increased citations

- maximum visibility for your research: over $100 \mathrm{M}$ website views per year

At $\mathrm{BMC}$, research is always in progress.

Learn more biomedcentral.com/submissions 